\title{
Value-Added Metabolites from Agricultural Waste and Application of Green Extraction Techniques
}

\author{
Muhammad Azri Amran ${ }^{1}\left(\mathbb{D}\right.$, Kishneth Palaniveloo $1, * \mathbb{C}$, Rosmadi Fauzi ${ }^{2}$, Nurulhuda Mohd Satar ${ }^{3}$, \\ Taznim Begam Mohd Mohidin ${ }^{4}$, Gokula Mohan ${ }^{4}$, Shariza Abdul Razak ${ }^{5}{ }^{\circ}$, Mirushan Arunasalam ${ }^{6}$, \\ Thilahgavani Nagappan ${ }^{7}\left(\mathbb{D}\right.$ and Jaya Seelan Sathiya Seelan ${ }^{8, *}$
}

1 Institute of Ocean and Earth Sciences, University of Malaya, Wilayah Persekutuan, Kuala Lumpur 50603, Malaysia; to.muhdazri@gmail.com

2 Department of Geography, Faculty of Arts and Social Sciences, University of Malaya, Wilayah Persekutuan, Kuala Lumpur 50603, Malaysia; rosmadifauzi@um.edu.my

3 Department of Economics and Applied Statistics, Faculty of Business and Economics, University of Malaya, Wilayah Persekutuan, Kuala Lumpur 50603, Malaysia; nurulhuda@um.edu.my

4 Faculty of Sciences, Institute of Biological Sciences, University of Malaya, Wilayah Persekutuan, Kuala Lumpur 50603, Malaysia; taznim@um.edu.my (T.B.M.M.); g.mohan@um.edu.my (G.M.)

5 Nutrition and Dietetics Program, School of Health Sciences, Health Campus, Universiti Sains Malaysia, Kubang Kerian 16150, Malaysia; shariza@usm.my

6 Faculty of Applied Sciences, UCSI University, Jalan Menara Gading 1, Taman Connaught, Cheras, Kuala Lumpur 56000, Malaysia; mirushan@ymail.com

check for

updates

Citation: Amran, M.A.; Palaniveloo, K.; Fauzi, R.; Mohd Satar, N.; Mohidin, T.B.M.; Mohan, G.; Razak, S.A.; Arunasalam, M.; Nagappan, T.; Jaya Seelan, S.S. Value-Added Metabolites from Agricultural Waste and Application of Green Extraction Techniques. Sustainability 2021, 13, 11432. https://doi.org/10.3390/ su132011432

Academic Editors: Anca Farcas and Sonia A. Socaci

Received: 2 September 2021

Accepted: 11 October 2021

Published: 16 October 2021

Publisher's Note: MDPI stays neutral with regard to jurisdictional claims in published maps and institutional affiliations.

Copyright: (C) 2021 by the authors. Licensee MDPI, Basel, Switzerland. This article is an open access article distributed under the terms and conditions of the Creative Commons Attribution (CC BY) license (https:// creativecommons.org/licenses/by/ $4.0 /)$.
7 Faculty of Marine and Environmental Sciences, Universiti Malaysia Terengganu, Kuala Terengganu 21030, Malaysia; thila.vani@umt.edu.my

8 Institute for Tropical Biology and Conservation, Universiti Malaysia Sabah, Jalan UMS, Kota Kinabalu 84000, Malaysia

* Correspondence: kishneth@um.edu.my (K.P.); seelan80@ums.edu.my (J.S.S.S.); Tel.: +60-13-878-9630 (K.P.); +60-13-555-6432 (J.S.S.S.)

\begin{abstract}
The agricultural sector generates approximately 1300 million tonnes of waste annually, where up to $50 \%$ comprising of raw material are discarded without treatment. Economic development and rising living standards have increased the quantity and complexity of waste generated resulting in environmental, health and economic issues. This calls for a greener waste management system such as valorization or recovery of waste into products. For successful implementation, social acceptance is an essential component with involvement of all local stakeholders including community to learn and understand the process and objective of the implementation. The agricultural waste product manufacturing industry is expected to increase with the growing demand for organic food. Thus, proper livestock and crop waste management is vital for environmental protection. It will be essential to successfully convert waste into a sustainable product that is reusable and circulated in the system in line with the green concept of circular economy. This review identifies the commercially produced crops by-product that have been considered for valorization and implemented green extraction for recovery. We highlight the importance of social acceptance and the economic value to agricultural waste recycling. Successful implementation of these technologies will overcome current waste management problems, reduce environmental impacts of landfills, and sustainability issue for farm owners.
\end{abstract}

Keywords: agriculture wastes; value-added metabolites; green extraction; circular economy

\section{Introduction}

Annually 1300 million tonnes of waste is generated from the agricultural sector. This number is expected to rise due to increase in demand for agricultural products [1] Agricultural waste comprises of manure, waste from farm, poultry houses, slaughterhouses or harvest waste such as fertilizers and pesticides. These wastes are often discarded without any recovery treatment. Agricultural wastes are regarded as underutilized low-value 
products. Economic development and rising living standards have resulted in increased quantity and complexity of generated waste making it a major contributor to waste disposal problems. Thus, recovery through conversion or processing of this waste is a recommended solution [2].

Agricultural wastes are generally categorized into crop waste; e.g., bagasse, culls from fruits and vegetables, prunings; livestock waste; e.g., manure, aminal, carcasses; food processing wastes; e.g., rice husk, wheat straw, jute fiber with crop waste (25-30\%) and animal waste (19-23\%) waste making up the largest contributors. On an average, $5.3 \mathrm{~kg} /$ day $/ 100 \mathrm{~kg}$ live weight (wet weight) of manure is generated in any agriculture farm [3]. Poorly managed agricultural waste generates biotic and abiotic by-products that could contaminate or degrade the environment, health and economy. The main cause of agricultural waste pollution is due to wastage, underutilization, poor awareness and treatment. Most agriculturists do not realize the importance of waste recycling and its economic potential [4]. Nowadays, the conversion of agricultural wastes into value added by-products through valorisation have gained considerable interest due to rising demand in the market for products with natural additives and stricter environmental regulations [5]. Agricultural wastes such as peels, stems, brans and seeds are generated in large amounts and is more nutritive compared to the raw material. These components account for more than $50 \%$ of the raw material [6]. Fruit and vegetable wastes are best sources of compounds such as polysaccharides, protein, phytochemicals, dietary fibre and flavour, known for their antioxidative, anti-inflammatory, anti-microbial and anti-allergenic properties [7]. Figure 1 shows the various niche areas related to agricultural wastes based on the number of keyword occurrences from 119 publications obtained from the ScienceDirect database.

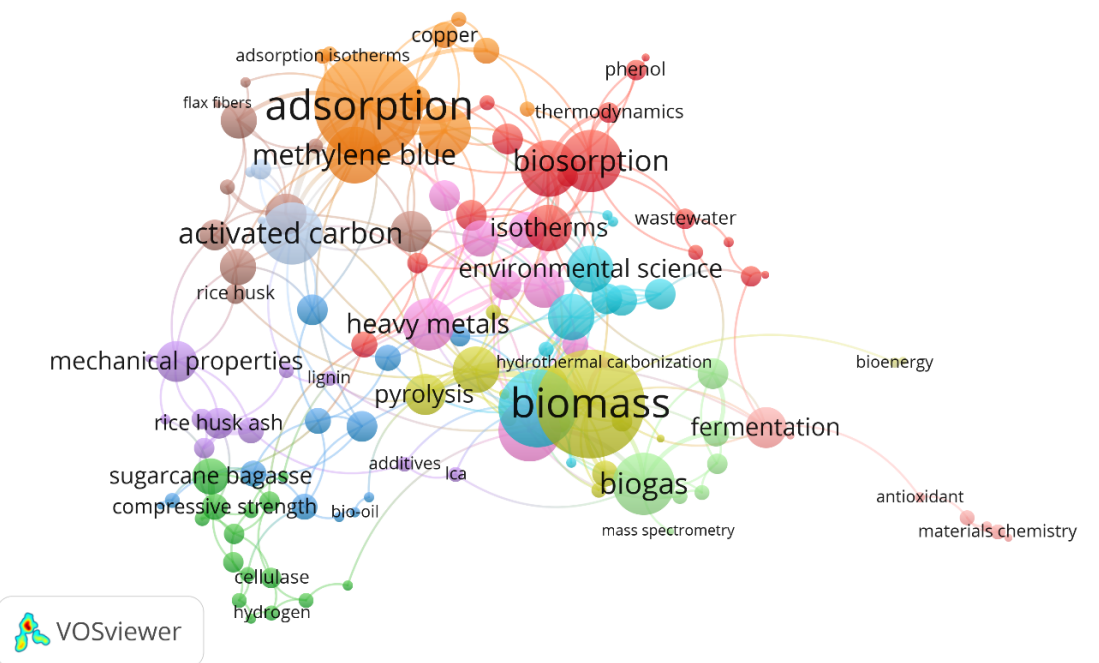

Figure 1. Keyword association map of agricultural wastes from 119 publication obtained from ScienceDirect database.

The importance of agricultural waste conversion into valuable by-products is translated into various sectors of the market. A recent study quantified the market of products from agricultural wastes in various sectors; highest at USD 63.3 billion in the beverage industry, followed by USD 48 billion in the medical industry, a total of USD 100 billion in the transportation, construction, medical industry and approximately USD 46 billion in the food and consumer goods sector [8]. Overall, valorisation of agricultural waste can improve the livelihood of the local communities through more income per harvest [6] while reducing excessive expenses for waste disposal and minimizing the carbon footprint in the process of reducing environmental impact [9]. Figure 2 is a simplified diagram of obtaining value-added by-products from the processing of agricultural input. 


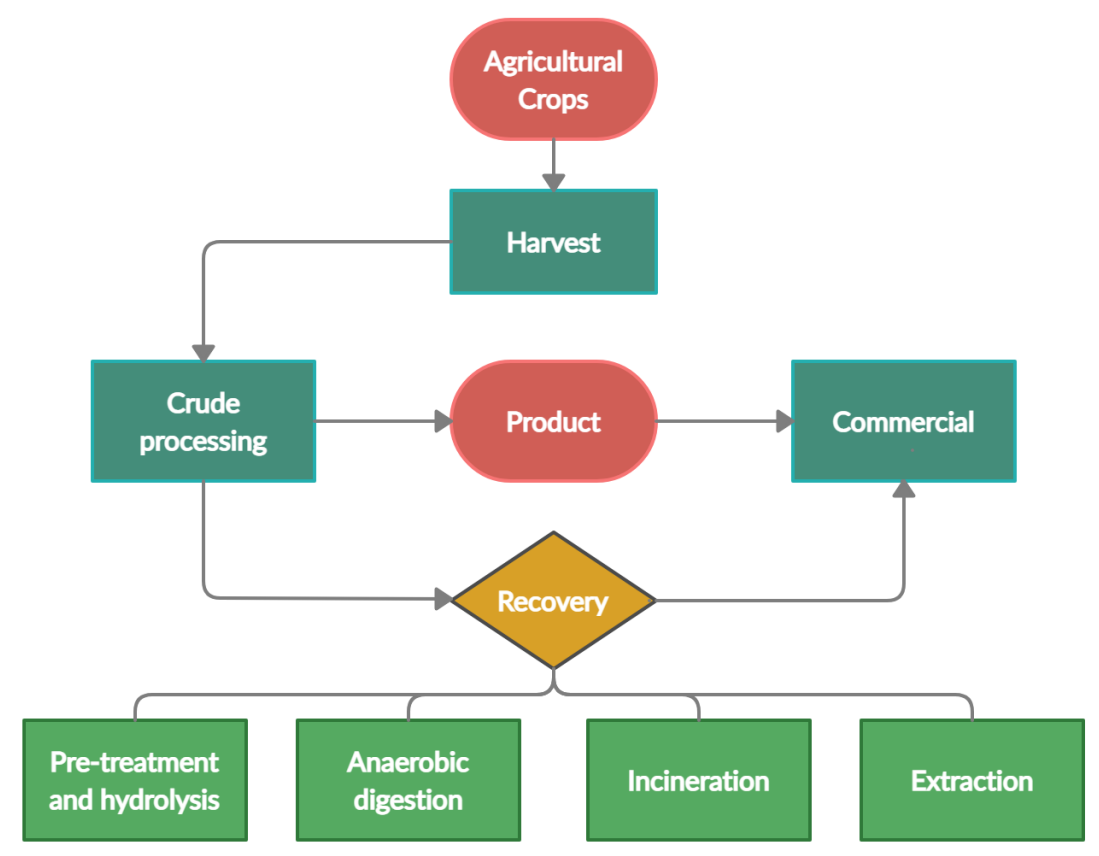

Figure 2. Value-added by-products from the processing of agricultural input.

\section{Perception of the Industry and Community in Waste Recycling}

Social acceptance is an essential part in the success of implementing waste valorization. Implementation of a new approach for recycling, fairs better when it includes all local stakeholders involved in waste generation [10]. The involvement of related parties in the decision-making process provides a chance to learn and understand the process and objective of implementation. It provides an opportunity for stakeholders to discuss unseen problems, create a public consensus on issues, identify possible solutions and uphold their commitment to the project [11]. This prevents conflicting issues from arising in the future, promotes mutual agreement among stakeholders [12] and increases the success rate of implementation.

To garner cooperation of public in recycling programs, it is important to understand the factors that influence behavior. Sociodemographic factors such as gender, age, income, and education have been found to be influential in community based programs. A study by Meneses et al. (2005) [13] determined that women are more likely to be engaged in household recycling than males. Similarly Li et al. (2012) [14] confirms that gender and age generate significant differences in household behavior where women and the elderly, above forty of age, display greater responsibility than men and the young [13].

Education is an important indicator to recycling behavior. Knowledge in waste recycling, reuse, recovery and composting can be achieved through early education. Recent findings on recycling behavior and attitude suggest that convenience, level of satisfaction toward recycling services, and economic incentives influence individual behavior and attitude toward recycling programs [11]. Combination of these characteristics may help to promote environmentally responsible behavior to support the recycling of wastes. Environmental awareness can be increased through environmental education where specified skills and expertise necessary to deal with the environmental challenges. It develops attitude, motivation, commitment to make decisions and take responsible actions [15]. Educated individuals are likely to engaged in recycling [16]. Handayani et al. (2019) [17] exhibited that the level of education and knowledge, as well as income level significantly influenced waste management behavior. The urban community, often individuals with higher education and income, are more likely to generate more waste and tendency to manage them well compared to rural areas. 


\section{Valorisation of Agricultural Waste}

Agricultural waste valorisation refers to industrial-scale processing of waste through composting or treatment for reusing or recycling, introduced as a solution to waste disposal and land-filling activities. It is performed in a larger magnitude to household waste as agricultural waste generated is non-hazardous, more homogeneous and greater in biomass. Waste valorisation goes with the concept that any residual material or by-product can be processed or converted into products and is circulated as long as possible in the production and consumption pipeline. The interest in waste valorisation among is mainly for the production of by-products for commercial purposes or as energy sources apart from an effective solution to waste related issues. Prior to the practice of converting waste through reuse and recycling into valuable by products, dumping and incineration is common. The 3Rs concept of Reduce, Recycle and Reuse is the most famous of efforts in waste management. Eventually, composting is practised to convert household wastes for agriculture utilization but it is plagued by issues such as scavenging animals and the lack of effort by society to maintain the composting process. The unpleasant smell makes composting effort less preferred at society level.

Agricultural-based industries produced vast amounts of residue annually, for instance, fruit peels form the juice industry, coffee pulp from the coffee industry and husks by the cereal and oil palm industry. Most agricultural wastes contain high nutritional properties and are of great value as by-products. Fruit peel and green walnut husks are natural anti-microbials and compost as a source of nutrient for plants, mushroom waste can be converted into food products and biofertilizers, while some are used as animal food [3]. Since some wastes are comprised of high amounts of proteins, sugars, and minerals, they serve potential as raw materials for the conversion and development into other valuable products. Table 1 lists the various agricultural wastes and the processing method suitable to maximize their health potentials. 
Table 1. Agricultural wastes and the processing method suitable to maximize its health potentials.

\begin{tabular}{|c|c|c|c|}
\hline Origin & Processing (Part) & Bioactivity and Compound Example & References \\
\hline Acorn & $\begin{array}{l}\text { Milling } \\
\text { - Hulls }\end{array}$ & $\begin{array}{l}\text { Anti-microbial, antioxidant } \\
\text { - Tannin }\end{array}$ & [18] \\
\hline Almond & $\begin{array}{l}\text { Blanching } \\
-\quad \text { Seeds }\end{array}$ & $\begin{array}{l}\text { Antioxidant, anti-microbial, anti-viral, dietary fibre, neuroprotective, photoprotective, prebiotic } \\
\text { - Catechin, kaempferol, isorhamnetin, naringenin, quercetin }\end{array}$ & [19] \\
\hline Apricot & $\begin{array}{l}\text { Grinding } \\
-\quad \text { Seed } \\
\text { Soaking } \\
-\quad \text { Pulp }\end{array}$ & $\begin{array}{l}\text { Anti-cancer, anti-inflammatory, anti-microbials, antioxidant, dietary fibre } \\
\text { - Amygdalin, b-glucosidase, cyanogenic glycosides, phenolics, tocopherols }\end{array}$ & {$[7,21]$} \\
\hline Avocado & $\begin{array}{l}\text { Peeling } \\
\text { - } \quad \text { Skin, Seed }\end{array}$ & $\begin{array}{l}\text { Anti-cancer, anti-inflammatory, antioxidant, dietary fibre, food additive } \\
\text { - Catechin, chlorogenic acid, cyanidin, epicatechin, gallic acid, hydroxybenzoic, hydroxycinnamic, } \\
\text { procyanidins, Quinic, 1-caffeoylquinic, 3-glucosidecitric, 3-O-p-coumaroylquinic, 4-caffeoylquinic }\end{array}$ & {$[7,24,25]$} \\
\hline Banana & $\begin{array}{l}\text { Milling } \\
\text { - Peel, Stalk } \\
\text { Pressing } \\
\text { - Pulp }\end{array}$ & $\begin{array}{l}\text { Anti-microbial, anti-inflammatory, antioxidant, dietary fibre, nutraceuticals } \\
\text { - Anthocyanins, auroxanthin, catecholamine, cyaniding, delphindin, gallocatechin, hydroxycinnamic, } \\
\text { flavonoids, isolutein, lutein, neoxanthin, phytosterols, proanthocyanidins, sterols, triterpenes, } \\
\text { violaxanthin, } \alpha \text {-carotene, } \beta \text {-carotene, } \alpha \text {-cryptoxanthin, } \beta \text {-cryptoxanthin }\end{array}$ & {$[7,22,24-26]$} \\
\hline
\end{tabular}


Table 1. Cont.

\begin{tabular}{|c|c|c|c|}
\hline Origin & Processing (Part) & Bioactivity and Compound Example & References \\
\hline Barley & $\begin{array}{l}\text { Milling } \\
\text { - Husk }\end{array}$ & $\begin{array}{l}\text { Anti-allergic, anti-cancer, anti-inflammatory, anti-microbial, anti-thrombotic, anti-viral } \\
\text { - Catechins, flavonoids, gallocatechin, cis-ferulic, trans-ferulic, trans-p-coumaric, proanthocyanidins, } \\
\text { procyanidin, tannins, vanillic }\end{array}$ & {$[24,27]$} \\
\hline Beetroot & $\begin{array}{l}\text { Peeling } \\
-\quad \text { Peel } \\
\text { Cutting } \\
\text { - Pulp, Crown }\end{array}$ & $\begin{array}{l}\text { Anti-anaemia, anti-cancer, anti-hypertensive, anti-inflammatory, anti-microbial, antioxidant, } \\
\text { food additive } \\
\text { - } \quad \text { Betalains, betacyanins, betaxanthin, catechin carotenoids, flavonoids, gallic, tannins }\end{array}$ & [7] \\
\hline Carrot & $\begin{array}{l}\text { Peeling } \\
-\quad \text { Skin } \\
\text { Pressing } \\
\text { - } \quad \text { Pulp }\end{array}$ & $\begin{array}{l}\text { Anti-inflammatory, Anti-microbial, anti-mutagenic, antioxidant, anti-viral, dietary fibre } \\
\text { - Anthocyanidin, carotene, carotenoids, flavonoids, lutein, polyphenols, pectin, tannins, } \alpha \text {-carotene, } \\
\beta \text {-carotene, } \alpha \text {-tocopherol }\end{array}$ & {$[7,22,24]$} \\
\hline Chestnut & $\begin{array}{l}\text { Milling } \\
\text { - Hull }\end{array}$ & $\begin{array}{l}\text { Anti-microbial, antioxidant } \\
\text { - Tannin }\end{array}$ & [18] \\
\hline Cocoa & $\begin{array}{l}\text { Grinding } \\
\text { - Shell, Skin } \\
\text { Pressing } \\
\text { - Husk }\end{array}$ & $\begin{array}{l}\text { Anti-microbial, antioxidant, dietary fibre, food additives, nutraceuticals, } \\
\text { - Arabinose, apigenin, catechin, epicatechin, epigallocatechin, galacturonic, galactose, gallocatechin, } \\
\text { kaempferol, linarin, luteolin, rhamnose, rhamnetin, protocatechuic C, p-shydroxybenzoic, xylose }\end{array}$ & [29] \\
\hline
\end{tabular}


Table 1. Cont

\begin{tabular}{|c|c|c|c|}
\hline Origin & Processing (Part) & Bioactivity and Compound Example & References \\
\hline Coffee & $\begin{array}{l}\text { Milling } \\
\text { - Husk } \\
\text { Roasting } \\
\text { - Pulp }\end{array}$ & $\begin{array}{l}\text { Anti-cancer, antioxidant, anti-viral, hepatoprotective, hypoglycaemic, nutraceuticals } \\
\text { - Anthocyanins, caffeine, caffeoylquinic, chlorogenic acid, dimethoxycinnamoyl quinic, di- } \\
\text { caffeoylquinic, diferuloylquinic, di-p-coumaroylquinic, dimethoxycinnamoyl feruloylquinic, } \\
\text { dimethoxycinnamoyl caffeoylquinic, feruloylquinic, feruloylcaffeoyl quinic, gallic, lignans, rutin, } \\
\text { protocatechuic, p-coumaroyl quinic, p-coumaroyl caffeoylquinic, p-coumaroyl feruloylquinic, p- } \\
\text { coumaroyl dimethoxycinnamoylquinic, tannins }\end{array}$ & {$[23,30,31]$} \\
\hline Corn & $\begin{array}{l}\text { Milling } \\
-\quad \text { Bran }\end{array}$ & $\begin{array}{l}\text { Antioxidant, dietary fibre } \\
\text { - Anthocyanins, caffeic, ferulic, p-coumaric, } p \text {-hydroxybenzoic, vanillic }\end{array}$ & {$[24]$} \\
\hline Cucumber & Peel & Caryophyllene, chlorophyll, pheophytin, phellandrene & {$[25]$} \\
\hline Date & Pulp, Seed & Antioxidant, dietary fibre & [24] \\
\hline Garlic & $\begin{array}{l}\text { Peeling } \\
\text { - } \quad \text { Straw, Husk }\end{array}$ & $\begin{array}{l}\text { Anti-microbial, antioxidant, dietary fibre } \\
\text { - Caffeic, di-ferulic, ferulic, } p \text {-coumaric }\end{array}$ & [7] \\
\hline Grape & $\begin{array}{l}\text { Stemming } \\
\text { - } \quad \text { Stalk } \\
\text { Pressing } \\
\text { - } \quad \text { Skin, Seed, Pulp }\end{array}$ & $\begin{array}{l}\text { Anti-carcinogenic, anti-inflammatory, antioxidant, dietary fibre, neuroprotective, nutraceutical } \\
\text { - Anthocyanins, caffeic, catechins, coumaric, ellagitannin, epicatechin, kaempferol, myricetin, resver- } \\
\text { atrol, rutin, tocopherols, tocotrienols, trans-resveratrol, protocatechuic, quercetin, syringic, vanillic }\end{array}$ & {$[9,21-23,32]$} \\
\hline Grapefruit & $\begin{array}{l}\text { Pressing } \\
\text { - Peel (albedo and flavedo), } \\
\quad \text { Rag and pulp, Seed }\end{array}$ & $\begin{array}{l}\text { Anti-allergic, anti-inflammatory, anti-microbial, antioxidant, anti-thrombotic, anti-viral, va- } \\
\text { sodilators } \\
\text { - Neohesperidosides, naringenin }\end{array}$ & {$[33]$} \\
\hline
\end{tabular}


Table 1. Cont.

\begin{tabular}{|c|c|c|c|}
\hline Origin & Processing (Part) & Bioactivity and Compound Example & References \\
\hline Green tea & $\begin{array}{l}\text { Soaking } \\
\text { Leaves }\end{array}$ & $\begin{array}{l}\text { Anti-microbial, antioxidant } \\
\text { - Catechins, chlorogenic acid, epicatechin, epigallocatechin, epigallocatechin gallate, flavonoids, } \\
\text { gallocatechin, glucosinolates, hydroxycinnamic, sinapic acid, tannin }\end{array}$ & {$[18,34]$} \\
\hline Guava & $\begin{array}{l}\text { Peeling } \\
\text { - Skin, Seed }\end{array}$ & $\begin{array}{l}\text { Antioxidant } \\
\text { - Catechin, cyanidin 3-glucoside, galangin, gallic, homogentisic, kaempferol }\end{array}$ & {$[25]$} \\
\hline Lemon & $\begin{array}{l}\text { Pressing } \\
\text { - Peel (albedo and flavedo), } \\
\quad \text { Rag and pulp, Seed }\end{array}$ & $\begin{array}{l}\text { Anti-allergic, anti-inflammatory, anti-microbial, antioxidant, anti-thrombotic, anti-viral, va- } \\
\text { sodilator } \\
\text { - Apigenin-6, caffeic, coumaric, ferullic, eriodictyol, neodiosmin, rutinosides, 8-di-C-glucoside }\end{array}$ & {$[33]$} \\
\hline Lime & $\begin{array}{l}\text { Pressing } \\
\text { - Peel (albedo and flavedo), } \\
\text { Rag and pulp, Seed }\end{array}$ & $\begin{array}{l}\text { Anti-allergic, anti-inflammatory, anti-microbial, antioxidant, anti-thrombotic, anti-viral, va- } \\
\text { sodilator } \\
\text { - Benzoic, catechin, caffeic, cholorgenic, ellagic, epicatechin, epigallocatechin gallate, eriocitrin, } \\
\text { ferullic, gallic, hesperidin, kaempferol, myricetin, naringin, naringenin, p-coumaric, protocatechuic, } \\
\text { quercetin, salicylic, vanillic }\end{array}$ & {$[33]$} \\
\hline Liquorice & $\begin{array}{l}\text { Cutting } \\
\text { - } \quad \text { Aerial part, Cortex root }\end{array}$ & $\begin{array}{l}\text { Anti-microbial, anti-inflammatory, antioxidant, anti-proliferative } \\
\text { - } \quad \text { Flavonoid, glabridin, isoliquiritigenin, licoricidin, licorisoflavan A }\end{array}$ & {$[35]$} \\
\hline Mandarin & $\begin{array}{l}\text { Pressing } \\
\text { - Peel (albedo and flavedo), } \\
\text { Rag and pulp, Seed }\end{array}$ & $\begin{array}{l}\text { Anti-allergics, anti-inflammatory, anti-microbial, antioxidant, anti-thrombotics, anti-virals, } \\
\text { vasodilators } \\
\text { - Caffeic, coumaric, ferullic, hesperidin, hesperetin-7-O-glucoside, hesperetin-7-O-rutinoside, } \\
\text { isosakuratenin-7-O-rutinoside, nobiletin, naringenin-7-O-rutinoside, tangeretin }\end{array}$ & {$[33]$} \\
\hline
\end{tabular}


Table 1. Cont

\begin{tabular}{lll}
\hline Origin & Processing (Part) & Bioactivity and Compound Example \\
\hline Mango & Peeling & Anti-inflammatory, antioxidant, dietary fibre, nutraceutical \\
& $-\quad$ Skin, Pulp, Seed & $\begin{array}{l}\text { Alkylresorcinols, flavonoids, gallates, gallotannins, hydrolysable tannins, methyl gallate, phenolics, } \\
\text { proanthocyanidins }\end{array}$
\end{tabular}

\begin{tabular}{lll}
\hline Olive & Milling & $\begin{array}{l}\text { Anti-atherogenic, anti-cancer, anti-microbial, anti-inflammatory, antioxidant, antiviral, hypolipi- } \\
\text { demic, hypoglycaemic }\end{array}$ \\
& $-\quad \begin{array}{l}\text { Apigenin, caffeic, hydroxytyrosol, kaempferol, luteolin, luteolin-7-glucoside, lignans, luteolin, } \\
\text { oleuropein, secoiridoid glycosides, tyrosol }\end{array}$
\end{tabular}

\begin{tabular}{|c|c|c|c|}
\hline Onion & $\begin{array}{l}\text { Peeling } \\
\text { - } \quad \text { Skin } \\
\text { Cutting } \\
\text { - } \quad \text { Leaves, Bulb }\end{array}$ & $\begin{array}{l}\text { Anti-cancer, anti-diabetic, anti-microbial, anti-inflammatory, antioxidant, dietary fibre, prebiotic } \\
\text { - Anthocyanins, aglycones, glycosylated, isorhamnetin 3,4'-diglucoside, isorhamnetin 3,4'-glucoside, } \\
\text { kaempferol, quercetin 3,4'-diglucoside, quercetin } 4^{\prime} \text {-glucoside, quercetin 3-glucoside }\end{array}$ & {$[7,22,35]$} \\
\hline Orange & $\begin{array}{l}\text { Pressing } \\
\text { - Peel (albedo and flavedo), } \\
\text { Rag and Pulp, Seed }\end{array}$ & $\begin{array}{l}\text { antioxidant, anti-inflammatory, anti-allergics, anti-thrombotics, anti-microbial, anti-viral, va- } \\
\text { sodilators, } \\
\text { - Caffeic, chrologenic, cinnamic, ferullic, p-Coumaric, heperetin, hesperidin, hesperetin-7-O- } \\
\text { rutinoside, hesperetin-7-O-glucoside, Isosakuratenin-7-O-rutinoside, kaempferide, nobiletin, neo- } \\
\text { diosmin, naringenin, naringenin-7-O-rutinoside, naringenin-7-O-neohesperoside, rutin, ruti- } \\
\text { noside, vanillin }\end{array}$ & [33] \\
\hline Papaya & $\begin{array}{l}\text { Grinding } \\
\text { - } \quad \text { Peel, Seed }\end{array}$ & $\begin{array}{l}\text { Anti-microbial, antioxidant, food additives } \\
\text { - Carotene, cryptoxanthin, lutein }\end{array}$ & [22] \\
\hline
\end{tabular}


Table 1. Cont.

\begin{tabular}{|c|c|c|c|}
\hline Origin & Processing (Part) & Bioactivity and Compound Example & References \\
\hline Peach & $\begin{array}{l}\text { Soaking } \\
-\quad \text { Skin } \\
\text { Grinding } \\
-\quad \text { Pulp }\end{array}$ & $\begin{array}{l}\text { Antioxidant } \\
\text { - Persipan, pectin }\end{array}$ & [21] \\
\hline Pineapple & $\begin{array}{l}\text { Milling } \\
\text { - Peel, Stem } \\
\text { Pressing } \\
\text { - Pulp }\end{array}$ & $\begin{array}{l}\text { Antioxidant, dietary fibre, prebiotic, probiotic } \\
\text { - } \quad \text { Bromelain, catechin, epicatechin, ferulic, gallic, phenolics }\end{array}$ & [22] \\
\hline Pomegranate & $\begin{array}{l}\text { Milling } \\
-\quad \text { Peel } \\
\text { Pressing } \\
-\quad \text { Pulp, Seed }\end{array}$ & $\begin{array}{l}\text { Anti-cancer, anti-diabetic, anti-inflammatory, anti-microbial, anti-mutagenic, antioxidant } \\
\text { - Anthocyanins, ellagitannins, flavonoids, gallic, punicalagin, punicalin }\end{array}$ & {$[23,24,37]$} \\
\hline Potato & $\begin{array}{l}\text { Cutting } \\
-\quad \text { Leaves, vines }\end{array}$ & $\begin{array}{l}\text { Peeling } \\
\text { - Peel, tuber } \\
\text { Antioxidant, biofuel, dietary fibre, soluble protein } \\
\text { - Anthocyanin, caffeic, carotenoid, lutein, 5-O-caffeoylquinic, 3-O-caffeoylquinic, 4-O-caffeoylquinic, } \\
\quad \text { 4,5-di-O-caffeoylquinic, 3,5-di-O-caffeoylquinic, 3,4-di-O-caffeoylquinic, 3,4,5-tri-O-caffeoylquinic }\end{array}$ & [38-48] \\
\hline Rice & $\begin{array}{l}\text { Dehulling } \\
\text { - } \quad \text { Straw } \\
\text { Milling } \\
\text { - Bran, husk }\end{array}$ & $\begin{array}{l}\text { Anti-cancer, anti-inflammatory, antioxidant, dietary fibre, food additive } \\
\text { - Anthocyanins, caffeic acid, cycloartenyl, ferulate, ferulic, niacin, oryzanol, pantothenic, pyridoxine, } \\
\text { phytosterols, tricin, tocopherols, tocotrienols, thiamine, transferulic, triterpene, } \gamma \text {-oryzanol }\end{array}$ & {$[24,25,28,49,50]$} \\
\hline
\end{tabular}


Table 1. Cont.

\begin{tabular}{|c|c|c|c|}
\hline Origin & Processing (Part) & Bioactivity and Compound Example & References \\
\hline Soybean & $\begin{array}{l}\text { Soaking } \\
\text { - Husk }\end{array}$ & $\begin{array}{l}\text { Antioxidant, dietary fibre, food additive, nutraceutical } \\
\text { - } \quad \text { Anthocyanins, daidzin, chlorogenic acid, ferulic, gallic, genistin, isoflavones, syringic }\end{array}$ & {$[51]$} \\
\hline Sweet potato & $\begin{array}{l}\text { Cutting } \\
\text { - } \quad \text { Leaves, vines } \\
\text { Peeling } \\
\text { - Peel, tuber }\end{array}$ & $\begin{array}{l}\text { antioxidant, biofuel, dietary fibre, phenolic compound, soluble protein } \\
\text { - Anthocyanin, caffeic, carotenoid, lutein, 5-O-caffeoylquinic, 3-O-caffeoylquinic, 4-O-caffeoylquinic, } \\
\text { 4,5-di-O-caffeoylquinic, 3,5-di-O-caffeoylquinic, 3,4-di-O-caffeoylquinic, 3,4,5-tri-O-caffeoylquinic }\end{array}$ & {$[52]$} \\
\hline Tomato & $\begin{array}{l}\text { Heating } \\
\text { - } \quad \text { Peel } \\
\text { Pressing } \\
\text { - } \quad \text { Seed, Pulp }\end{array}$ & $\begin{array}{l}\text { Anticancer, anti-cholesterol, antioxidant, dietary fibre, food additive } \\
\text { - Caffeic, chlorogenic acid, } \beta \text {-carotene, ferulic, lycopene, quercetin, quercetin-3- } \beta \text {-O-glycoside, } \\
\text { naringenin glycosylated, rutin }\end{array}$ & {$[5,7,22,24]$} \\
\hline Wheat & $\begin{array}{l}\text { Milling } \\
\text { - } \quad \text { Bran }\end{array}$ & $\begin{array}{l}\text { Anti-cancer, antioxidant, dietary fibre } \\
\text { - } \quad \text { Caffeic, ferulic, gallic, p-coumaric, synergic, vanillic }\end{array}$ & {$[24]$} \\
\hline
\end{tabular}




\section{Potential By-Products from Agriculture Waste}

Poorly managed agricultural waste does not provide any form of value, instead they cost financially more to manage and leads to environmental burden. Conversion of agricultural wastes into valuable by-products and the technology to produce these products are constantly developing with consideration of environmental conditions, economic situation and societal response or acceptance [48]. In line with the 'Green Chemistry' principle, agricultural wastes can be extracted and converted into various applications such as functional food, flavour, fertilizer or biofuel for industries such as food and beverage, pharmaceutical, agriculture and renewable energy. Some wastes are comprised of high amounts of nutritional components such as protein, sugar or mineral, while others can be an important source of bioactive compounds such as phenolics and carotenoids which contribute to antioxidative properties [6]. Compounds such as essential oil, $\beta$-glucans, volatile flavourings or natural colourings are proposed as health promoting additives in the food industry due to their antimicrobial and antioxidative properties [6]. Fibres which are made up of polysaccharides and lignins are crucial in functional foods [28]. Antioxidant and antimicrobial properties exhibited by compounds such as hydrooxytyrosol in wheat bran for instance is useful during postharvest processing for packaging or extending shelf life of crops [53]. Husks from cereals are used as components in bio-composites for packaging. Recently, rice husk is also being used in cow dung composting for production of fertilizers. The application of agricultural wastes also extends to production of biofuel as a form of renewable energy and animal feed.

\subsection{Phenolics}

Phenolics are bioactive secondary metabolites inessential for the survival of plants. They exhibit antioxidant, antimicrobial, anticarcinogenic and several other beneficial health effects. In potato peels, polyphenols are enriched as an allelochemical in the tuber to prevent microbial infection. Potatoes are heavily used therefore generate enormous amounts of wastes. Processing the peel leads to the extraction of phenolics, which are important antioxidants. Ferulic, chlorogenic acid and caffeic acid are the most abundant phenolic acids while gallic acid, protocatechuic acid, coumaric acid, syringic acid, vanillic acid and p-hydroxy benzoic acid have also been reported from potato peel. The application of fermentation to break down fermentable sugars on potato waste can trigger the conversion of starch into valuable compounds with the aid of acids or enzymes while producing ethanol as a by-product that can be used as biofuel.

Rice bran is one of the most underutilized by-products of rice which can be a source for anticancer products. Phenolic compounds from rice bran such as caffeic acid, ferulate and ferulic acid have the potential to prevent a range of chronic diseases such as colon and human breast cancer. Phenols, tricin and ferulic acid in rice bran have exhibited apoptosis and inhibition of cancerous cell proliferation [54]. Rice bran also consists of rich dietary fiber which helps to prevent overeating by inducing the feeling of fullness and help to maintain weight. The intake of dietary fiber can help lower blood cholesterol, blood pressure, and enhance humans' insulin sensitivity [55].

Citrus peel contains antioxidative polyphenolic such as phenolic acids, flavanones, flavanol, and flavones that can reduce the risk of cancer by inhibiting tumor formation. Citrus peel extract which contain tangeretin and nobiletin can help reduce cholesterol in the treatment of hypercholesterolemia and hypertriglyceridemia [56]. Citrus peel also consists of sudachitin which enhances energy utilization and fatty acid $\beta$-oxidation through the stimulation of mitochondria in skeletal muscle. Sudachitin can be potentially used for its anti-diabetic and anti-obesity properties [57]. Some citrus peel also consist of the flavone naringenin, a neuroprotective agent with anti-amnestic function and is also useful in the prevention of neurodegenerative disease such as Alzheimer's disease [58]. The antioxidant and anti-inflammatory properties of hesperidin, naringin, diosmin and apigenin present in citrus peel also has anti-aging properties and prohibits other degenerative related diseases [59]. These compounds in the citrus peel can be isolated by solid-liquid as well as liquid-liquid methods of extraction [60]. 


\subsection{Alkaloids}

The use of herbicides, pesticides, insecticides and the various chemicals in agriculture results in the accumulation of toxins in agricultural waste. Potatoes for example has toxins in their peel as the primary defence against pathogens [48]. Approximately 140,000 tonnes of peel are generated through the consumption of potatoes, however due to the toxin composition it is only used as animal feed. Potatoes are rich in steroidal alkaloids. Characterization and separation of the toxins from agricultural input is necessary for its conversion in order to obtain value added products that are safe both for human and the environment. Steroidal alkaloid is a class of toxic secondary metabolite commonly associated with anti-bacterial, anti-fungal and insect repelling properties [48]. These compounds can cause colic pain, diarrhea, gastroenteritis, vomiting, fever, low blood pressure, rapid pulse and neurological disorders in human when ingested in high quantities [48]. Among the most common in potatoes are $\alpha$-solanine and $\alpha$-chaconine. The presence of glycosidic chains in these compounds contribute to the cytotoxic effects of these alkaloids by inhibiting the acetyl cholinesterase enzyme, cellular membrane and calcium transport as well as able to harm nerve cells at low concentrations of $\mathrm{IC}_{50}=4.1 \mu \mathrm{M}$.

\subsection{Aroma, Flavour and Fragrance}

Extraction of aroma has been done since ancient times but nowadays its extraction is performed at an industrial scale. Various techniques are applied for the extraction of volatiles of different nature. The most preferred way to obtain natural aroma from raw material is through alcoholic extraction and the application of mild temperature. Centrifugation recovers hydrophobic organic volatiles. The extraction of essential oil can be extracted with the use of very volatile organic solvents such as hexane or n-pentane. However, nowadays external enzymes are introduced to enhance metabolic pathways to trigger the production of more volatiles [48]. Potatoes are known to have a markedly greater ratio of pyrazines to aldehydes in the peels than the pulp. Pyrazines can reach up to $73 \%$ while 2,5 - and, or 2,6-dimethylpyrazine being the most common compound in the peels.

\subsection{Production of Food Microorganisms}

The utilization of agricultural wastes to produce beneficial microorganisms like biocontrol agents, baker's yeast, brewer's yeast or probiotic cultures is rare as these are mostly processed for their secondary metabolites or microbial proteins. Microbial proteins are dried microorganisms (bacteria, fungi and algae) extracted to be used as animal feed and supplement. Potato residues, oil mill wastewater, fruit pomaces, whey, molasses and lignocellulosic biomass have been applied to produce microbial protein [48].

For the processing of potato peels, Saccharomyces cerevisiae is commonly used for the production of microbial protein and production of secondary metabolites from raw material due to its ability to metabolize glucose, fructose and sucrose. The potato wastewater is used for the production of Bacillus thuringiensis, while potato starch is a suitable medium of the culture of Schanniomyces alluvius [40]. Other strains, such as Rhizopus oryzae, have been used to processing potato peels for the production of chitosan [45], Aspergillus niger for the production of glucoamylase, lactic acid bacteria Lactobacillus rhamnosus for the production of lactic acid [46], and Bacillus subtilis for the production of biosurfactant [44]. Microorganisms play a vital role in the valorization of organic material and the diversity of microbes vary during each stage of conversion. The microbial community profile during various stages of food waste composting has been comprehensively reviewed by Palaniveloo et al. (2020) [61].

\subsection{Organic Fertilizers and Feed}

Composting of rice straw along with farm wastes could be used for soil fertility and suppression of soil-borne diseases. Rice straw incorporated with cattle manure or municipal sludge was used in rapid composting to produce a higher nutrient fertilizers. Such compost was integrated in fungicide management practices to reduce synthetic fungicide usage and leachate discharge [62]. Rice straw contains $34.2 \%$ cellulose and $27.9 \%$ hemi-celluloses, 
and 10.2\% lignin making it a good fodder for animal feeding. Common in Asia, this fodder undergoes ammonization to increase its urea or ammonia to recommended levels of $4 \mathrm{~kg}$ urea per $100 \mathrm{~kg}$ air-dry straw before fed to animals [62].

Rice husk contains $15 \%$ carbon, $18 \%$ ash, and $67 \%$ volatile matter that is formed from two polyphenolic compounds, silica and lignin. The lignin and silica content enables the husk to exhibit antioxidant and antifungal properties. The high lignin content is also used for soil fertilization, while potassium and silicon are used for soil amendment. Rice husk has also been used as a substitute for wood shavings and sawdust in poultry houses and litters [49]. Substituting these also have an impact on poultry farm performance where bird reared on rice husk shows the highest weight gain. The other tough part of rice husk can also be used as an additive for animal foods and as a source of fiber. Rice hulls can also be an anti-caking agent to reduce food clumping.

\subsection{Nutraceuticals}

Citrus peel fiber has been shown to be beneficial for intestinal health and function. Its dietary fiber consists of cellulose, pectin, hemicellulose, and lignin which plays an important role in maintaining a balanced dietary fiber intake. The citrus peel fiber is comparatively better than cereal fibers due to its higher soluble dietary fiber ratio and the presence of bioactive compounds such as flavonoids, polyphenols, carotenoids, and vitamin C [33]. Dietary fiber originated from fruit by-product have also been associated with antioxidant properties which can be unbounded by heat treatments to improve the polyphenolic content such as in gastrointestinal digestion [63]. Regular consumption of dietary fiber also helps in the prevention, reduction, and treatment of various chronic diseases, such as, diabetes, obesity, cardiovascular diseases, gastrointestinal diseases, and also cancer [64]. In addition, citrus fiber also lowers blood triglycerides which help in glucose homeostasis [33]. The citrus peel is also beneficial to health due to their antioxidant properties as well as their capability to retain a high amount of water and oil [65].

Among the coffee by-products which are, coffee pulp, cherry husk, silver skin, and spent wastes, the coffee silver skin contains the highest amount of total fiber. Coffee fiber consists of cellulose, hemicelluloses, pectin, lignin, and other polysaccharides. Coffee fiber has a wide range of potential health benefits such as reducing the risks of obesity, gastrointestinal diseases, and cardiovascular diseases [66]. Coffee by-product also provides beneficiary effects of both dietary fiber and antioxidant properties rather than just a fiber component such as in cereal [67].

\subsection{Other Components from Agricultural Wastes}

The by-product from washed and rasped potatoes contains proteins ( $35 \% \mathrm{of} \mathrm{dm}$ ) sugar (5\% of $\mathrm{dm})$, minerals $(20 \%$ of $\mathrm{dm})$ and organic acids $(4 \%$ of $\mathrm{dm})$ for every $5 \%$ dry matter (dm) [38]. The potato protein comprises of patatin, a protease inhibitor, high-molecularweight proteins and is rich in lysine (7.18\%) and methionine (1.06\%) [38]. Being high in nutritional value, protein rich agricultural wastes need to be processed to be reused sustainably. Potato fruit juice for instance is commonly used as fertilizer. Alternatively, purification of the potato by-product is proposed for the recovery of high-value ingredients. The use of ion-exchange or adsorption by bentonite precipitates proteins [42].

The introduction of acidic components such a citric acid, ferric chloride or organic solvent additives promotes precipitation to obtain the soluble protein [39]. Eventually, after the processing of raw material, the remains need to be considered for recycling. Potato pulp for instance is valued at approximately 0.75 tons per ton of purified starch and this varies with the raw material and processes applied. Potato pulp is quantified to contain starch $(37 \%$ of dry matter, $\mathrm{dm})$, cellulose $(17 \%$ of $\mathrm{dm})$, pectin $(17 \% \mathrm{of} \mathrm{dm})$, hemicellulose $(14 \%$ of $\mathrm{dm})$, fibers $(7 \%$ of $\mathrm{dm})$ protein/amino acids and ash $(4 \%$ of $\mathrm{dm}$ respectively) [43]. Before treatment, it can function as a medium for yeast growth in vitamin B12 production or be used in biogas production. Partially dried pulp is very suitable as poultry food to avoid decomposition while dehydrated material can be processed in the 
paper industry [41]. Nowadays, the extraction of galactan-rich rhamnogalacturonan I from potato pectic polysaccharides is gaining fame for its health benefits [47]. Further application of potato pulps as raw waste includes its use as fertilizers upon extraction of nitrogen containing substances, the production of alcohol through fermentation of hydrolysed pulp and is being considered for incorporation into gluten-free biscuits [68].

The use of agricultural by-products is capable to reduce the cost of enzymes production at an industrial level that uses submerged fermentation [69]. Agricultural by-products such as coffee husk, has also been used along with Paecilomyces variotii in the production of caffeinase, pectinase, and tannase [70]. The coffee by-products also have been used to produce enzymes like protease, amylase, and xylanase using fungal organisms such as, Aspergillus oryzae, Penicillium sp., Aspergillus niger, and Neurosporacrassa [71]. Figure 3 exhibits the chemical structures of some agricultural wastes metabolites with antioxidative properties.<smiles>COc1cc(/C=C/C(=O)O)ccc1O</smiles>

Hydrocinnamic acid<smiles>O=C(O)/C=C\c1ccc(O)c(O)c1</smiles><smiles>O=C1CC(c2ccc(O)cc2)Oc2cc(O)cc(O)c21</smiles>

Flavanones<smiles>O=C(O)c1cc(O)c(O)c(O)c1</smiles>

Hydrobenzoic acid<smiles>COc1ccc(C2CC(=O)c3c(O)cc(O)cc3O2)cc1O</smiles><smiles>O=c1cc(-c2ccccc2)oc2ccccc12</smiles>

Flavone<smiles>O=c1c(O)c(-c2ccc(O)c(O)c2)oc2cc(O)cc(O)c12</smiles>

Flavonol<smiles>O=c1c(-c2ccc(O)cc2)coc2cc(O)cc(O)c12</smiles>

Isoflavone<smiles>Oc1cc(O)c2c(c1)OC(c1ccc(O)c(O)c1)C(OC1(c3ccc(O)c(O)c3)Oc3cc(O)cc(O)c3C(O)C1O)C2</smiles>

Proanthocyanidin

Figure 3. Chemical structures of some agricultural wastes metabolites with antioxidative properties.

\section{Importance of Sustainable Extraction Approaches}

\subsection{Green Extraction}

The food processing industry has observed tremendous growth over the last decade resulting in significant quantities of wastes being generated [72]. Agricultural wastes, mainly fruits and vegetables are rich in probiotics, dietary fiber, carotenoids, fatty acids, phenolic compounds, isoprenoids, lipids, proteins, saponins, and phytoestrogens making them an important source for development into functional foods, nutraceuticals and cosmetics. Various parts of these wastes (stem, leaves, peel, seed, and roots) and the residues from their juices, oils, starch, and sugars contain these compounds in large quantities [36]. Carotenoids and phenolics are among the key components responsible for the bioactivity against cancer, as well as inflammatory and cardiovascular diseases [25]. Targeted components as well as transformed by-products such as nutraceuticals, enzymes, 
bioplastics, biofuel are some examples that can be obtained and is of value to the agriculture, nutraceutical and food industries.

The impact of agricultural waste is rather heightened compared to its production and consumption [73] as if not disposed of or treated, cause serious environmental hazards. Untreated rotting waste produces substantial amount of methane gas which contributes 25 times more towards global warming than $\mathrm{CO}_{2}$ [74]. In order to overcome these issues valorization of wastes into various value-added products or the extraction of bioactive compounds with various functional benefits is much needed [72]. The use of optimized extraction protocols aim to maximize the yield of bioactive compounds or nutritional components to meet the demands of industrial processing while avoiding deterioration and degradation of functionality of input [75]. Prior to extracting any complex constituent from a biological source, it has to be released from the cellular matrix into a suitable solvent [76]. Traditional extraction techniques are even commonly used in domestic applications such as making coffee or tea which involves solid-liquid extraction (SLE) principle by means of solvent application and leaching. SLE encompasses conventional methods such as Soxhlet extraction (SE), maceration extraction (ME) and percolation [77].

On an industrial scale, organic solvents extraction technique is commonly utilised [78]. The uneconomical; time, energy and labour intensive and toxic nature of conventional solvent extraction which requires large amounts of solvents may cause degradation of target molecules, loss of volatiles coupled, low extraction yield and presence of solvent residue [78-80] had driven research towards a low-cost, eco-friendly, and efficient extraction techniques, based on a green philosophy $[80,81]$. 'Green extraction' is defined based on twelve principles of green chemistry and green engineering [82] from which six principles of green extraction was established $[83,84]$. The six principles of green extractions are: (1) Innovation through varieties and renewable plant resources, (2) Usage of alternative solvents, (3) Reduction of energy consumption through energy recovery and innovative technologies, (4) Production of alternative products, (5) Reduction in operations and development of a sustainable industry, and (6) Application of green extraction.

Under this concept, the conservation of biodiversity is made priority through the utilization of renewable resources and in vitro cultivation. This can be done using techniques such as plant milking where plants are cultivated in liquid medium to accumulate targeted chemicals secreted into the medium through external stimulation. Though bound to be extracted, solvents that are physically and chemically stable with low volatility, easy to use and recycle, if possible, reusable are utilized, in favour of sustainability and environmental protection. Supercritical fluids such as $\mathrm{CO}_{2}$ and water, organic salt-based solvents such as ionic liquids and deep eutectic solvents are considered as green solvents while solvents such as ethanol, terpenes, glycerol and methyl esters of fatty acids in vegetable oil are considered as agro-solvents. All extraction and separation process needs to be done in a energy efficient manner which focused on optimizing production process that will significantly reduce the usage of energy and raw material, waste generation, and environmental impact. This can be approached by the assistance of innovative technology and processes. The end goal of this principle is to optimize the use of resources sustainably and develop value-added products free of pollutants such as heavy metals, pesticide residues and heavy metals mycotoxins, instead of waste through bio- and agro- refinery concepts. The drawbacks in existing conventional processes and the quality criteria extract must meet, there is no guarantee of its harmlessness to man and the environment $[83,84]$. The concept of green extraction of natural products not only protect both the consumer and environment but also enhance the competition within industries to be more innovative, ecological and economical [85]. Figure 4 provides an overview in the application of green principle in agricultural waste valorization in a circular economy concept. 


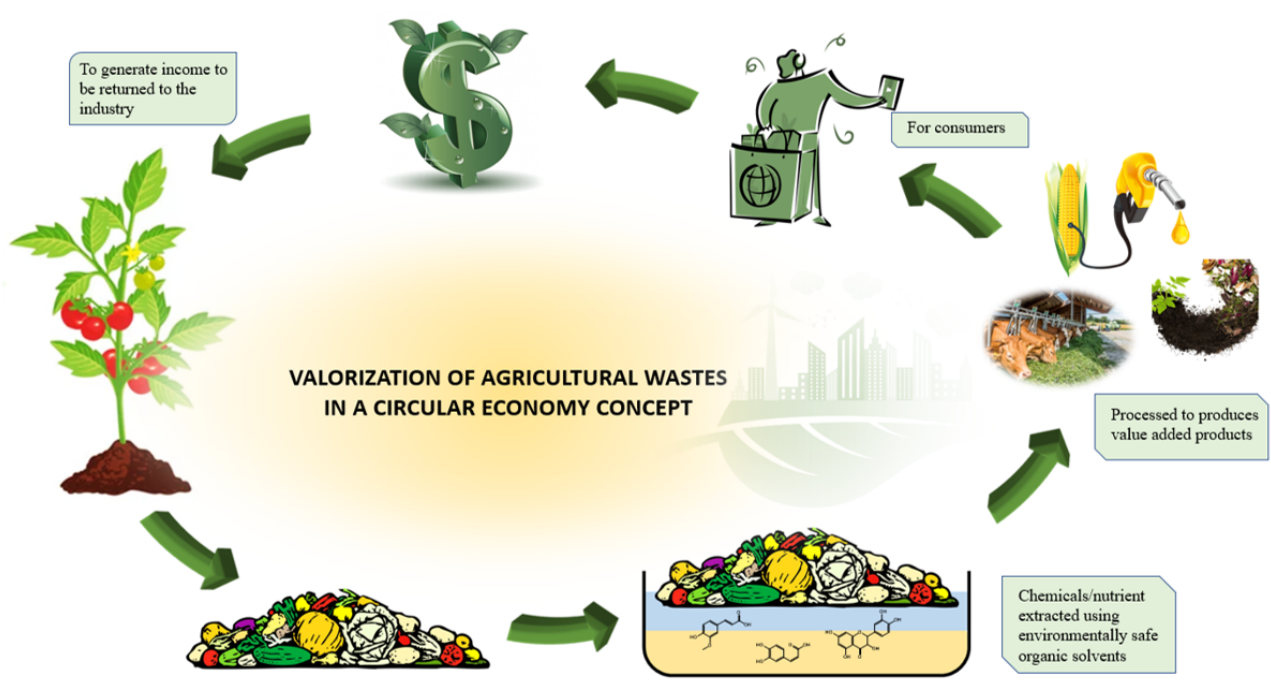

Figure 4. The application of green principle in agricultural waste valorization in a circular economy concept.

There have been numerous successful implementation of the green extraction on an industrial scale. In the development of the anti-cancer paclitaxel (Taxol®), this compound was extracted from the bark of the western Yew (Taxus brevifolia) in the 1970's. Naturally, the extraction of $1 \mathrm{~kg}$ purified taxol, requires $10 \mathrm{~kg}$ of dry bark, thus a clinical trial needed approximately 30 tonnes of bark and is not sustainable. Eventually, the discovery of a feasible quantity of 10-deacetylbaccatin III (10-DAB III) from the leaves of European Yew made it a much sustainable source compared to the bark of Taxus brevifolia [84]. In the extraction of mechanical oil from Jatropha curcas L seeds, the application of green extraction was done by optimizing the extraction approach. Its learnt that the different energy input and material throughput effect the volume of oil recovery, therefore optimization by finding an optimal middle ground between specific energy input and material throughput maximized oil recovery [86].

The implementation of alternative or solvent-free extraction, such as microwave hydrodiffusion and gravity (MHG), pulsed electric field, and instantaneous controlled pressure drop have successfully shown to reduce overall extraction cost, reduce solvent related risks, facilitate in scaling up process, and improve the purity of extracts. These techniques remove wastewater post-treatment and requires less energy compared to conventional solvent extraction. MHG have been efficient in both lab and industrial scale extraction of antioxidants, pigments, and aroma components from plant sources [87]. In the fresh juice production industry, more than 1 million tonnes of orange peel waste (peel, pulp and seed) is generated anually and sold as cheap cattle feed. Adoption of green extraction techniques such as wave hydrodistillation and microwave hydrodiffusion and gravity (MHG) have successfully recovered numerous value added compounds such as pectin, enzymes, flavonoids, citric acid, ascorbic acid, dietary fibres and essential oils (D-limonene) [84]. Putnik et al. (2018) [88] reported the successful extraction of pectin, polyphenols, and essential oil using the solvent-free ultrasound-assisted extraction (UAE) and microwave-assisted extraction (MAE) through exploiting in situ water which can be recycled and cost efficient. The use of UAE was exceptionally more efficient in polyphenols extraction while MAE was also more efficient at pectin extraction compare to conventional method with higher yield and a lower extraction time. 
In this section an overview on the applications of green extraction techniques such as supercritical fluid extraction (SFE), ultrasound-assisted extraction (UAE) and microwave assisted extraction (MAE) will be discussed as an alternative to the conventional extraction methods such as Soxhlet extraction (SE), maceration extraction (ME) and percolation. Figure 5 shows a flow of optimizing extraction and the use of green extraction techniques. A comparison of SFE, UAE and MAE techniques is also provided in Table 2.

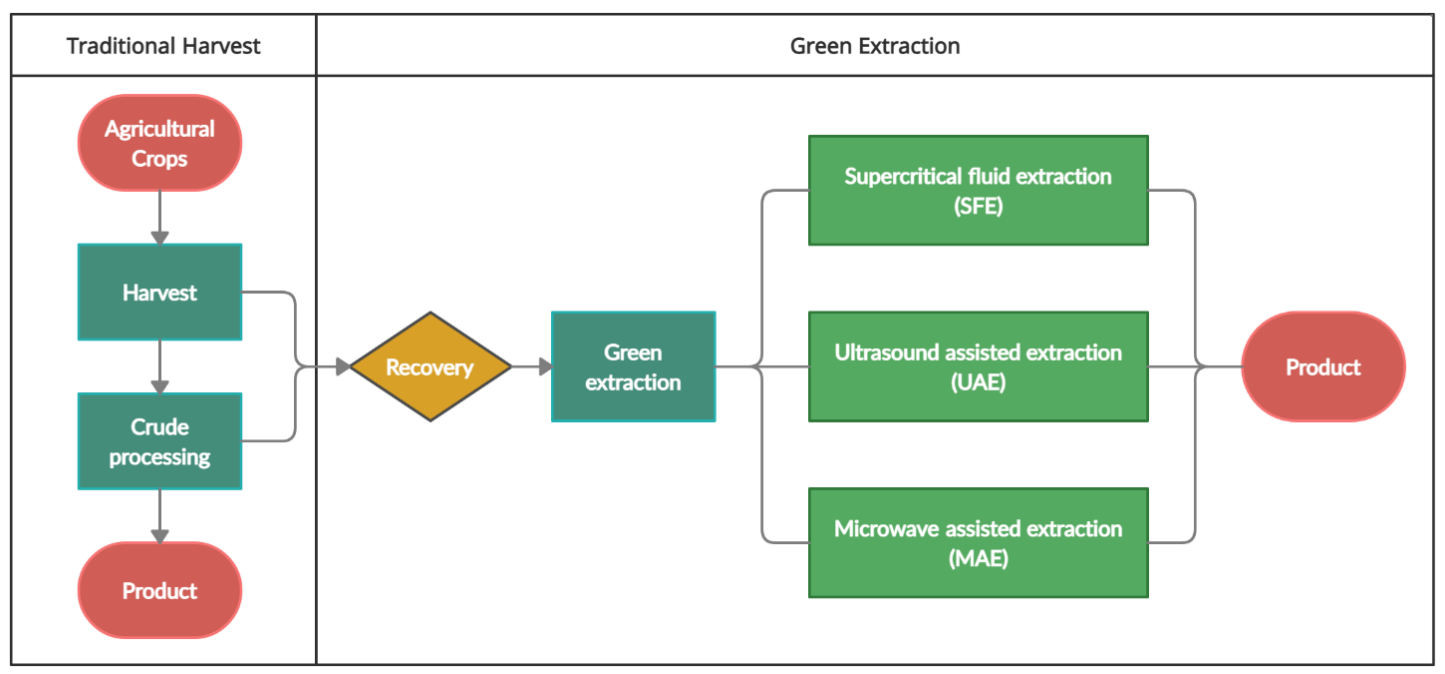

Figure 5. The use of green extraction techniques in optimization of agricultural wastes processing.

\subsubsection{Supercritical Fluid Extraction (SFE)}

Supercritical fluid extraction is a solid-fluid extraction technique in which fluid in their supercritical state is employed to solvate the solid matrix and extract the solute contained within the matrix [89]. Supercritical fluids (SCFs) are substances that are at a pressure and temperature above their critical values. The basic principle of SFE is that at supercritical conditions, no liquid-gas phase boundary and surface tension exists. The SCFs behaves as a single phase, retaining the properties of both gas and liquid at the same time. The fluid diffuses into the solid matrix like a gas and dissolves active compounds like a liquid [90]. The solvent power of SCFs is the highest for non-polar or slightly polar components and decreases with increasing molecular weight [91].

Supercritical fluid possesses gas-like properties of diffusion, viscosity, surface tension, liquid-like density and solvation power. These properties make it suitable to extract compounds in a short time with higher yield [92]. Slight variations in the temperature and pressure causes a significant change in properties of SCFs [90] and they can easily be removed from the solutes by expansion to ambient pressure [91]. A basic SFE system consists of the following parts: a mobile phase, a pump to pressurize the gas, co-solvent vessel and pump, an oven that contains the extraction vessel, a controller to maintain the high pressure inside the system and a trapping vessel. Usually, different types of meters like flow meter, dry/wet gas meter could be attached to the system [93].

The most common fluid for SFE is carbon dioxide, $\mathrm{CO}_{2}$, favoured due to its nontoxic, low cost, non- flammable, chemically inert, available in high quantity and quality. The critical temperature of $\mathrm{CO}_{2}$ is close to ambient at $31{ }^{\circ} \mathrm{C}$ hence, minimising the need for heating to reach its critical temperature. The high pressure of $\mathrm{CO}_{2}$ of $73 \mathrm{~atm}$ is suitable for lab scale or pilot plant operation set up $[90,94]$. Extraction with supercritical solvents is suitable for solute isolating from natural materials, because the extract is obtained at a relatively low temperature and without any trace of organic solvent. $\mathrm{CO}_{2}$ can be easily separated from the extract simply by exposing the gas to room conditions $\left(25^{\circ} \mathrm{C}, 1 \mathrm{~atm}\right)[90]$. However, the drawback of using super critical $\mathrm{CO}_{2}$ as a solvent is that it is very non-polar in nature. It has a polarity comparable to liquid pentane, making it compatible with 
low polarity compounds such as fatty acids, triglycerides, carotenoids and aroma but unsuitable for the extraction of polar compounds [95]. This limitation can be overcome by using co-solvents such as ethanol and methanol [95] which is widely used to modify the polarity of the supercritical fluids and improve the solvating power to enhance its extraction efficiency by minimizing the interactions between the analyte and the matrix with respect to targeted biologically active compounds [72].

Compounds reported to be isolated using SFE technique are carotenoids from waste vegetable matrices such as flesh and peels of sweet potato, tomato, apricot, pumpkin, peach [96] and polyphenol from Lupinus luteus seed [97]. Reviews on the extraction of flavors, fragrances and other natural products using SFE has also been previously published and their vast application in extraction of non-polar compounds such as essential oils, lipids, carotenes, carotenoids and alkaloids has also been investigated [98-102].

\subsubsection{Ultrasound-Assisted Extraction (UAE)}

Ultrasound-assisted extraction (UAE) uses ultrasound as a pre-treatment or during solid-liquid extraction (SLE) process. Ultrasonic waves encompasses frequencies that are above the audible range (up to $20 \mathrm{kHz}$ ) and less than microwave frequency (up to to $10 \mathrm{MHz})$. Ultrasound can be further classified as low-intensity sonication $\left(1 \mathrm{~W} / \mathrm{cm}^{2}\right)$ and high-intensity sonication $\left(10-1000 \mathrm{~W} / \mathrm{cm}^{2}\right)$. Low-intensity sonication is commonly employed for quality assurance and process control as a non-destructive analytical technique, especially of those involving physiochemical properties, such as structure, composition and physical state of matter while high-intensity sonication is used for extraction and processing applications. The alternating pressure changes causes the formation and collapse of bubbles in a liquid medium. It is this phenomenon of creation, expansion, and implosive collapse of microbubbles in ultrasound-irradiated liquids is known as "acoustic cavitation", which is he principle driving force of sonication. The implosions generated results in temperature and pressure changes which causes cell disruption and thinning of the cell membrane. This process aids the penetration of extraction solvents into the cells and amplifies the mass transfer of the target compound into the solvent [80].

Factors such as frequency, ultrasonic power, temperature, design of the reactor, extraction solvents used, solvent to sample ratio, particle size and structure need to be considered when employing UAE. At low intensities of ultrasonic power, the external and internal mass transfer resistances are affected while not affecting the product structure. Intermediate intensity affects the product structure and a further increase in the ultrasonic power can cause disintegration of the cells. Hence, UAE requires optimization when scaling from a laboratory set up to an industrial scale while maintaining lowest consumption of monetary and energy [103]. Ultrasound can also be employed in super critical fluid extraction (SFE) to produce agitation as mechanical stirrers are not possible in SFE and enhance the mass transfer of compound of interest from the solid matrix into to the extraction solvent [104]. Compounds such as aroma, antioxidants, pigments, phenol, carotenoids and anthocyanins have been efficiently extracted using UAE [85,104-106].

\subsubsection{Microwave-Assisted Extraction (MAE)}

Microwave-assisted extraction (MAE) is a method which employs microwave energy in combination with traditional solvent extraction techniques [107]. During microwave, solvent to absorbs microwave energy and pass it on as heat to the surrounding molecules. Solvents with high dielectric constants such as water have a better ability to absorb microwave energy [108]. In MAE, heating occurs in a targeted and selective manner with practically no heat being lost to the environment as the heating occurs in a closed system, unlike conventional heating [109]. A considerable amount of pressure builds up in the biological material during microwave heating which alters the physical properties of the tissues thus improving the porosity of the biological matrix which allows better penetration of the extraction solvent [110]. 
Microwaves are non-ionizing electromagnetic waves positioned between the X-ray and infrared rays in the electromagnetic spectrum with a frequency range between $300 \mathrm{MHz}$ to $300 \mathrm{GHz}$ [109]. The principle of heating molecules using microwave energy is based on the direct effect of microwaves on the molecules through ionic conduction and dipole rotation. Ionic conduction is the electrophoretic migration of ions when an electromagnetic field is applied. Heat is produced by the resistance of the solution to the flow of ions which results in friction and thus heat being produced. Dipole rotation is the realignment of dipoles with the applied field. At the frequency commonly used in commercial systems $(2450 \mathrm{MHz})$ the dipoles align and randomize at a rate of $4.93 \times 10^{9}$ times per second and this forced molecular movement results in heat being generated. These two mechanisms take place simultaneously in most applications [111]. During microwave heating, the hydrogen bond are disrupted promoted by the dipole rotation of molecules which takes place with related heat discharged. The migration of dissolved ions which intensifies the penetration of the solvents into the matrix hence facilitating the extraction of target compounds [109]. The increased pressure also leads to cell swelling and forces the cells to split [112]. Compounds such as antioxidants, polyphenols, flavonoids, essential oils and taxanes have been reported to be successfully extracted using MAE [113-118]. 
Table 2. Comparison in the characteristics of the various green extraction technique.

\begin{tabular}{|c|c|c|c|}
\hline \multicolumn{4}{|c|}{ Extraction Technique } \\
\hline & SFE & UAE & MAE \\
\hline Advantage [111] & $\begin{array}{l}\text { 1. Minimal solvent usage } \\
\text { 2. Fast extraction process } \\
\text { 3. Fairly selective towards matrix interference } \\
\text { 4. Concentrated extract can be obtained } \\
\text { 5. Automation } \\
\text { 6. Doesn't require filtration and cleaning up } \\
\text { 7. } \\
\text { Elocess }\end{array}$ & $\begin{array}{l}\text { 1. Multiple extraction } \\
\text { 2. Low investment }\end{array}$ & $\begin{array}{l}\text { 1. Minimal solvent usage } \\
\text { 2. Quick and multiple extraction } \\
\text { 3. Elevated temperature } \\
\text { 4. } \quad \text { Moderate investment }\end{array}$ \\
\hline Drawback [111] & $\begin{array}{l}\text { 1. Requires optimization of multiple parame- } \\
\text { ters } \\
\text { 2. High investment }\end{array}$ & $\begin{array}{l}\text { 1. Requires large volume of solvent } \\
\text { 2. May require repeated extraction } \\
\text { 3. Requires clean-up step }\end{array}$ & $\begin{array}{l}\text { 1. Solvent used should be compatible with } \\
\text { microwave heating } \\
\text { 2. Requires clean-up step } \\
\text { 3. Time consuming for vessel to cool down }\end{array}$ \\
\hline $\begin{array}{l}\text { Compounds } \\
\text { Isolated } \\
{[85,96-102,104-} \\
106,113-118]\end{array}$ & $\begin{array}{ll}\text { 1. } & \text { Carotenoids } \\
\text { 2. } & \text { Polyphenols } \\
\text { 3. } & \text { Flavors } \\
\text { 4. } & \text { Fragrances } \\
\text { 5. } & \text { Lipids } \\
\text { 6. } & \text { Carotenes } \\
\text { 7. } & \text { Alkaloids } \\
\text { 8. } & \text { Tocopherols } \\
\text { 9. } & \text { Tocotrienol } \\
\text { 10. } & \text { Carotenoids } \\
\text { 11. } & \text { Essential oils }\end{array}$ & $\begin{array}{ll}\text { 1. } & \text { Aromas } \\
\text { 2. } & \text { Antioxidants } \\
\text { 3. } & \text { Pigments } \\
\text { 4. } & \text { Phenols } \\
\text { 5. } & \text { Polyphenols } \\
\text { 6. } & \text { Carotenoids } \\
\text { 7. } & \text { Anthocyanins }\end{array}$ & $\begin{array}{ll}\text { 1. } & \text { Polyphenols } \\
\text { 2. } & \text { Essential oils } \\
\text { 3. } & \text { Taxanes } \\
\text { 4. } & \text { Antioxidants } \\
\text { 5. } & \text { Flavonoids }\end{array}$ \\
\hline
\end{tabular}




\section{Economic and Market Demand}

\subsection{Economic Analysis}

Agricultural wastes from agro-based industries such as palm oil, rubber and wood processing factories have increased by more than threefold. These residues can be used as an alternate source for the production of different products like biogas, biofuel, mushroom, and tempeh as the raw material in various research and industries [119]. The reuse of agro-industrial wastes as raw materials can help to reduce the production cost and reduce the pollution load from the environment. The way forward to reduce the agricultural waste disposal rate is through recycling or waste minimization at the source [120]. The importance of recycling agricultural waste has been widely recognized in both developed and developing countries. For instance, over 110,000 biogas projects originating from agricultural waste have been initiated in rural China [121]. The agricultural waste recycling economy is well accepted in countries like the United States, Germany, the Netherlands, Korea, Japan, and South Africa, growing in demand and becoming a priority in economic policy as an investment during the modernization and urbanization [122].

Although utilization of agricultural waste and its by-product contributes positively to environmental sustainability, for small scale farmers, the process cost of recycling agricultural waste is a major obstacle compared to incinerating which is far more cost-efficient [26]. Lack of government incentives, high cost of agricultural waste disposal, inadequate finance and equipment are among the major problems faced by the small-scale farmer [123]. As a result, many small-scale farmers are unwilling to be involved in agricultural waste extraction. Din and Cohen (2013) believes that this is due to lack of public awareness and community involvement, lack of mandatory and environmental regulations and enforcement. Additionally poor accessibility within the city, collection route system and schedule distances a small-scale farmers from agricultural waste recycling [124]. The high cost of disposal is the biggest challenge of all as it involves transportation, distribution, storage, and facility. This situation has led to chronic waste management problems especially in the low-income countries where small-scale farmers facing problems with disposing and recycling agricultural waste [3].

\subsection{Market Demand and Economic Value}

Agricultural waste and its by-products are defined as non-food based plant or animal residues that can cause environmental and economic burden in the farming and primary processing sectors [125]. In the livestock industry, the production of meat, milk and eggs generates large amounts of waste. If these wastes are not adequately managed, the risks of water pollution from excess nitrates or carbon, air pollution by greenhouse gas emissions and soil pollution due to the accumulation of nutrients is evident. Animal wastes are often associated with health risks to humans and animals if not managed [126]. Nowadays, there is an increasing demand for agricultural waste products. According to Gontard et al. (2018) the demand for agricultural waste products is influenced by awareness towards the benefits of agricultural waste products and a growing number of small and medium-scale manufacturers in North America and Europe. In Asia Pacific and Middle East, the demand is expected to grow at a slower rate from lack of awareness and loose regulatory framework. In the biochar industry, manufacturing requires huge capital investment, setting a barrier to entry to ensure profitability. As a consequence, companies operating at a non-optimal scale of operation may not survive therefore requires collaboration with research groups and institutions as established by China, Japan, Brazil, and Mexico.

In time, the agricultural waste product manufacturing industry is expected to increase with the growing demand for organic food, driving proper livestock and crop waste management, vital to environmental protection. Thus, circular economy becomes essential by converting waste into a sustainable health product that is reusable and circulated in the system. For instance, manures, that is valuable organic fertilizers for maintenance of soil fertility and crop production can also be used for biogas generation. Similarly, plant residues can be used as animal feed, to produce biofuels, fertilize the soil and protect it 
from erosion or generate alternative products. In this circular concept, the role of Research and Development (R\&D) industry is crucial to develop product from recycling agricultural waste to fulfill market demands [126].

\section{Conclusions}

The valorization of agricultural wastes offers tons of exploitable opportunity in economic, environmental, and social aspects. As mentioned in this paper almost all of the presently commercialized agriculture crops by-products have the potential to be recovered as a value-added product. Using appropriate extraction method, it is also possible for the recovery process to be environmental friendly and also to ensure its sustainability in the industrial process. In addition, it could also create new job opportunities following the new recovery process chain. The use of agricultural waste is also a powerful tool to tackle current global issues such as waste disposal, landfill reserve and food shortages. However, further development still needed to fully integrate the still-evolving valorization system into an effective sustainable industrial tool. In the same context, there is also possible synergy between agricultural waste usage in wastewater and solid waste treatment.

Author Contributions: Conceptualization, K.P.; validation, K.P., R.F., N.M.S., T.B.M.M., G.M., M.A.A. and T.N.; formal analysis, M.A.A.; investigation, M.A.A.; resources, K.P., R.F., N.M.S., M.A.A. and M.A.; data curation, M.A.A. and M.A.; writing-original draft preparation, M.A.A. and M.A.; writing-review and editing, K.P., R.F., N.M.S., T.B.M.M., G.M., T.N., S.A.R., M.A.A. and J.S.S.S.; supervision, K.P.; project administration, K.P.; funding acquisition, S.A.R. and J.S.S.S. All authors have read and agreed to the published version of the manuscript.

Funding: Universiti Malaya Grant Number RP029(A-C)-18SUS and SDN 004 UMS Skim Dana Niche. Institutional Review Board Statement: Not applicable.

Informed Consent Statement: Not applicable.

Acknowledgments: Authors acknowledge the Universiti Malaya Sustainability Cluster and the Universiti Malaysia Sabah Skim Dana Niche for the grants which resulted to the preparation of this manuscript.

Conflicts of Interest: The authors declare no conflict of interest.

\section{References}

1. Gustavsson, J.; Cederberg, C.; Sonesson, U.; Van Otterdijk, R.; Meybeck, A. Global food losses and food waste. In Proceedings of the Save Food Congress, Düsseldorf, Germany, 16-17 May 2011.

2. Cho, E.J.; Trinh, L.T.P.; Song, Y.; Lee, Y.G.; Bae, H.J. Bioconversion of biomass waste into high value chemicals. Bioresour. Technol. 2020, 298, 122386. [CrossRef] [PubMed]

3. Obi, F.O.; Ugwuishiwu, B.O.; Nwakaire, J.N. Agricultural waste concept, generation, utilization and management. Niger. J. Technol. 2016, 35, 957-964. [CrossRef]

4. Shehrawat, P.; Sindhu, N. Agricultural waste utilization for healthy environment and sustainable lifestyle. Ann. Agric. Biol. Res 2015, 20, 110-114.

5. Szabo, K.; Dulf, F.V.; Diaconeasa, Z.; Vodnar, D.C. Antimicrobial and antioxidant properties of tomato processing byproducts and their correlation with the biochemical composition. LWT 2019, 116, 108558. [CrossRef]

6. Singh, K.; Kumar, T.; Prince, V.K.; Sharma, S.; Rani, J. A review on conversion of food wastes and by-products into value added products. IJCS 2019, 7, 2068-2073.

7. Coman, V.; Teleky, B.E.; Mitrea, L.; Martau, G.A.; Szabo, K.; Calinoiu, L.F.; Vodnar, D.C. Bioactive potential of fruit and vegetable wastes. In Advances in Food and Nutrition Research; Toldra, F., Ed.; Academic Press: Cambridge, MA, USA, 2020; Volume 91, pp. 157-225.

8. Beltrán-Ramírez, F.; Orona-Tamayo, D.; Cornejo-Corona, I.; González-Cervantes, J.L.N.; de Jesús Esparza-Claudio, J.; QuintanaRodríguez, E. Agro-Industrial Waste Revalorization: The Growing Biorefinery. Biomass for Bioenergy-Recent Trends and Future Challenges. IntechOpen 2019, 21. [CrossRef]

9. Lucarini, M.; Durazzo, A.; Romani, A.; Campo, M.; Lombardi-Boccia, G.; Cecchini, F. Bio-based compounds from grape seeds: A biorefinery approach. Molecules 2018, 23, 1888. [CrossRef]

10. Hoang, G.M.; Fujiwara, T.; Phu, T.S.P.; Nguyen, L.D. Sustainable solid waste management system using multi-objective decisionmaking model: A method for maximizing social acceptance in Hoi An city, Vietnam. Environ. Sci. Pollut. Res. 2019, 26, 34137-34147. [CrossRef] 
11. Bom, U.B.; Belbase, S.; Bibriven Lila, R. Public Perceptions and Practices of Solid Waste Recycling in the City of Laramie in Wyoming, U.S.A. Recycling 2017, 2, 11. [CrossRef]

12. Morone, P.; Imbert, E. Food waste and social acceptance of a circular bioeconomy: The role of stakeholders. Curr. Opin. Green Sustain. Chem. 2020, 23, 55-60. [CrossRef]

13. Meneses, G.D.; Palacio, A.B. Recycling behavior a multidimensional approach. Environ. Behav. 2005, 37, 837-860. [CrossRef]

14. Li, Y.M.; Bai, J.F.; Wang, J.X.; Qiu, H.G. Disposal of domestic solid wastes and determinants in rural China. China Popul. Resour. Environ. 2012, 22, 63-68.

15. Leicht, A.; Heiss, J.; Byun, W.J. (Eds.) Issues and Trends in Education for Sustainable Development; UNESCO: Paris, France, 2018.

16. Thomas, C.; Sharp, V. Understanding the normalisation of recycling behaviour and its implications for other pro-environmental behaviours: A review of social norms and recycling. Resour. Conserv. Recycl. 2013, 79, 11-20. [CrossRef]

17. Handayani, D.; Gitaharie, B.Y.; Yussac, R.N.; Rahmani, R.S. How do household characteristics influence their waste management? E3S Web Conf. 2019, 74, 06005. [CrossRef]

18. Sung, S.H.; Kim, K.H.; Jeon, B.T.; Cheong, S.H.; Park, J.H.; Kim, D.H.; Kweon, H.J.; Moon, S.H. Antibacterial and antioxidant activities of tannins extracted from agricultural by-products. J. Med. Plants Res. 2012, 6, 3072-3079. [CrossRef]

19. Chen, C.Y.O.; Milbury, P.E.; Blumberg, J.B. Polyphenols in almond skins after blanching modulate plasma biomarkers of oxidative stress in healthy humans. Antioxidants 2019, 8, 95. [CrossRef]

20. Amin, I.; Mukhrizah, O. Antioxidant capacity of methanolic and water extracts prepared from food-processing by-products. J. Sci. Food Agric. 2006, 86, 778-784. [CrossRef]

21. Schieber, A.; Stintzing, F.C.; Carle, R. By-products of plant food processing as a source of functional compounds-Recent developments. Trends Food Sci. Technol. 2001, 12, 401-413. [CrossRef]

22. Fermoso, F.G.; Serrano, A.; Alonso-Farinas, B.; Fernandez-Bolanos, J.; Borja, R.; Rodriguez-Gutierrez, G. Valuable compound extraction, anaerobic digestion, and composting: A leading biorefinery approach for agricultural wastes. J. Agric. Food Chem. 2018, 66, 8451-8468. [CrossRef] [PubMed]

23. Mourtzinos, I.; Goula, A. Polyphenols in agricultural byproducts and food waste. In Polyphenols in Plants; Elsevier: Amsterdam, The Netherlands, 2019; pp. 23-44.

24. Tlais, A.Z.A.; Fiorino, G.M.; Polo, A.; Filannino, P.; Di Cagno, R. High-value compounds in fruit, vegetable and cereal byproducts: An overview of potential sustainable reuse and exploitation. Molecules 2020, 25, 2987. [CrossRef] [PubMed]

25. Kumar, K.; Yadav, A.N.; Kumar, V.; Vyas, P.; Dhaliwal, H.S. Food waste: A potential bioresource for extraction of nutraceuticals and bioactive compounds. Bioresour. Bioprocess. 2017, 4, 1-14. [CrossRef]

26. Padam, B.S.; Tin, H.S.; Chye, F.Y.; Abdullah, M.I. Banana by-products: An under-utilized renewable food biomass with great potential. J. Food Sci. Technol. 2014, 51, 3527-3545. [CrossRef]

27. Gupta, M.; Abu-Ghannam, N.; Gallaghar, E. Barley for brewing: Characteristic changes during malting, brewing and applications of its by-products. Compr. Rev. Food Sci. Food Saf. 2010, 9, 318-328. [CrossRef]

28. Routray, W.; Orsat, V. Plant by-products and food industry waste: A source of nutraceuticals and biopolymers. In Food Bioconversion; Grumezescu, A.M. and Holban, A.M., Eds.; Academic Press: Cambridge, MA, USA, 2017; Volume 2, pp. $279-315$.

29. Campos-Vega, R.; Nieto-Figueroa, K.H.; Oomah, B.D. Cocoa (Theobroma Cacao L.) Pod Husk: Renewable Source bioactive Compounds. Trends Food Sci. Technol. 2018, 81, 172-184. [CrossRef]

30. Esquivel, P.; Jimenez, V.M. Functional properties of coffee and coffee by-products. Food Res. Int. 2012, 46, 488-495. [CrossRef]

31. Murthy, P.S.; Naidu, M.M. Production and application of xylanase from Penicillium sp. utilizing coffee by-products. Food Bioprocess Technol. 2012, 5, 657-664. [CrossRef]

32. Shrikhande, A.J. Wine by-products with health benefits. Food Res. Int. 2000, 33, 469-474. [CrossRef]

33. Fernandez-Fernandez, A.M.; Dellacassa, E.; Medrano-Fernandez, A.; Del Castillo, M.D. Citrus waste recovery for sustainable nutrition and health. In Food Wastes and By-Products: Nutraceutical and Health Potential; Campos-Vega, R., Oomah, B.D., VergaraCastaneda, H.A., Eds.; Blackwell Publishing: Hoboken, NJ, USA, 2020; pp. 193-222.

34. Dominguez-Perles, R.; Moreno, D.A.; Carvajal, M.; Garcia-Viguera, C. Composition and antioxidant capacity of a novel beverage produced with green tea and minimally-processed byproducts of broccoli. Innov. Food Sci. Emerg. Technol. 2011, 12, 361-368. [CrossRef]

35. Aiello, F.; Armentano, B.; Polera, N.; Carullo, G.; Loizzo, M.R.; Bonesi, M.; Cappello, M.S.; Capobianco, L.; Tundis, R. From vegetable waste to new agents for potential health applications: Antioxidant properties and effects of extracts, fractions and pinocembrin from Glycyrrhiza glabra L. aerial parts on viability of five human cancer cell lines. J. Agric. Food Chem. 2017, 65, 7944-7954. [CrossRef] [PubMed]

36. Wall-Medrano, A.; Olivas-Aguirre, F.J.; Ayala-Zavala, J.F.; Domínguez-Avila, J.A.; Gonzalez-Aguilar, G.A.; Herrera-Cazares, L.A.; Gaytan-Martinez, M. Health Benefits of Mango By-products. In Food Wastes and By-Products: Nutraceutical and Health Potential; Campos-Vega, R., Oomah, B.D., Vergara-Castaneda, H.A., Eds.; Blackwell Publishing: Hoboken, NJ, USA, 2020 ; pp. $159-191$.

37. Meselhy, K.M.; Shams, M.M.; Sherif, N.H.; El-Sonbaty, S.M. Phytochemical study, potential cytotoxic and antioxidant activities of selected food byproducts (Pomegranate peel, Rice bran, Rice straw \& Mulberry bark). Nat. Prod. Res. 2020, 34, 530-533.

38. Knorr, D.; Kohler, G.O.; Betschart, A.A. Potato protein concentrates: The influence of various methods of recovery upon yield, compositional and functional characteristics. J. Food Process. Preserv. 1977, 1, 235-247. [CrossRef] 
39. Knorr, D. Effect of recovery methods on yield, quality and functional properties of potato protein concentrates. J. Food Sci. 1980, 45, 1183-1186. [CrossRef]

40. Calleja, G.B.; Yaguchi, M.; Levy-Rick, S.; Seguin, J.R.H.; Roy, C.; Lusena, C.V. Single-cell protein production from potato starch by the yeast Schwanniomyces alluvius. J. Ferment. Technol. 1986, 64, 71-75. [CrossRef]

41. Slominska, L.; Starogardzka, G. Application of a Multi-enzyme Complex in the Utilization of Potato Pulp. Starch Stärke 1987, 39 , 121-125. [CrossRef]

42. Gonzalez, J.M.; Lindamood, J.B.; Desai, N. Recovery of protein from potato plant waste effluents by complexation with carboxymethylcellulose. Food Hydrocoll. 1991, 4, 355-363. [CrossRef]

43. Mayer, F. Potato pulp: Properties, physical modification and applications. Polym. Degrad. Stab. 1998, 59, 231-235. [CrossRef]

44. Fox, S.L.; Bala, G.A. Production of surfactant from Bacillus subtilis ATCC 21332 using potato substrates. Bioresour. Technol. 2000, 75, 235-240. [CrossRef]

45. Kleekayai, T.; Suntornsuk, W. Production and characterization of chitosan obtained from Rhizopus oryzae grown on potato chip processing waste. World J. Microbiol. Biotechnol. 2011, 27, 1145-1154. [CrossRef]

46. Izmirlioglu, G.; Demirci, A. Strain selection and medium optimization for glucoamylase production from industrial potato waste by Aspergillus niger. J. Sci. Food Agric. 2016, 96, 2788-2795. [CrossRef]

47. Khodaei, N.; Karboune, S.; Orsat, V. Microwave-assisted alkaline extraction of galactan-rich rhamnogalacturonan I from potato cell wall by-product. Food Chem. 2016, 190, 495-505. [CrossRef]

48. Fritsch, C.; Staebler, A.; Happel, A.; Cubero Márquez, M.A.; Aguiló-Aguayo, I.; Abadias, M.; Gallur, M.; Cigognini, I.M.; Montanari, A.; López, M.J.; Suárez-Estrella, F. Processing, valorization and application of bio-waste derived compounds from potato, tomato, olive and cereals: A review. Sustainability 2017, 9, 1492. [CrossRef]

49. Bodie, A.R.; Micciche, A.C.; Atungulu, G.G.; Rothrock Jr, M.J.; Ricke, S.C. Current trends of rice milling byproducts for agricultural applications and alternative food production systems. Front. Sustain. Food Syst. 2019, 3, 47. [CrossRef]

50. Peanparkdee, M.; Iwamoto, S. Bioactive compounds from by-products of rice cultivation and rice processing: Extraction and application in the food and pharmaceutical industries. Trends Food Sci. Technol. 2019, 86, 109-117. [CrossRef]

51. Tyug, T.S.; Prasad, K.N.; Ismail, A. Antioxidant capacity, phenolics and isoflavones in soybean by-products. Food Chem. 2010, 123, 583-589. [CrossRef]

52. Akoetey, W.; Britain, M.M.; Morawicki, R.O. Potential use of byproducts from cultivation and processing of sweet potatoes. Cienc. Rural 2017, 47, e20160610 . [CrossRef]

53. Hamza, M.; Sayadi, S. Valorisation of olive mill wastewater by enhancement of natural hydroxytyrosol recovery. Int. J. Food Sci. Technol. 2015, 50, 826-833. [CrossRef]

54. Henderson, A.J.; Ollila, C.A.; Kumar, A.; Borresen, E.C.; Raina, K.; Agarwal, R.; Ryan, E.P. Chemopreventive properties of dietary rice bran: Current status and future prospects. Adv. Nutr. 2012, 3, 643-653. [CrossRef]

55. Gul, K.; Yousuf, B.; Singh, A.K.; Singh, P.; Wani, A.A. Rice bran: Nutritional values and its emerging potential for development of functional food-A review. Bioact. Carbohydrates Diet. Fibre 2015, 6, 24-30. [CrossRef]

56. Kurowska, E.M.; Manthey, J.A. Hypolipidemic effects and absorption of citrus polymethoxylated flavones in hamsters with diet-induced hypercholesterolemia. J. Agric. Food Chem. 2004, 52, 2879-2886. [CrossRef] [PubMed]

57. Tsutsumi, R.; Yoshida, T.; Nii, Y.; Okahisa, N.; Iwata, S.; Tsukayama, M.; Hashimoto, R.; Taniguchi, Y.; Sakaue, H.; Hosaka, T.; Shuto, E. Sudachitin, a polymethoxylated flavone, improves glucose and lipid metabolism by increasing mitochondrial biogenesis in skeletal muscle. Nutr. Metab. 2014, 11, 1-14. [CrossRef] [PubMed]

58. Heo, H.J.; Kim, M.J.; Lee, J.M.; Choi, S.J.; Cho, H.Y.; Hong, B.; Kim, H.K.; Kim, E.; Shin, D.H. Naringenin from Citrus junos has an inhibitory effect on acetylcholinesterase and a mitigating effect on amnesia. Dement. Geriatr. Cogn. Disord. 2004, 17, 151-157. [CrossRef] [PubMed]

59. Ashraf, H.; Butt, M.S.; Iqbal, M.J.; Suleria, H.A.R. Citrus peel extract and powder attenuate hypercholesterolemia and hyperglycemia using rodent experimental modeling. Asian Pac. J. Trop. Biomed. 2017, 7, 870-880. [CrossRef]

60. Valenti, F.; Porto, S.M.C.; Chinnici, G.; Selvaggi, R.; Cascone, G.; Arcidiacono, C.; Pecorino, B. Use of citrus pulp for biogas production: A GIS analysis of citrus-growing areas and processing industries in South Italy. Land Use Policy 2017, 66, 151-161. [CrossRef]

61. Palaniveloo, K.; Amran, M.A.; Norhashim, N.A.; Mohamad-Fauzi, N.; Peng-Hui, F.; Hui-Wen, L.; Kai-Lin, Y.; Jiale, L.; Chian-Yee, M.G.; Jing-Yi, L.; Gunasekaran, B. Food waste composting and microbial community structure profiling. Processes 2020, 8, 723. [CrossRef]

62. Camilia, E.D.; Zaghloul, A.; Fikry, A.W.A.D. Utilization of rice straw as a low-cost natural by-product in agriculture. Int. J. Environ. Pollut. Environ. Model. 2018, 1, 91-102.

63. Gutiérrez Barrutia, M.B.; Curutchet, A.; Arcia, P.; Cozzano, S. New functional ingredient from orange juice byproduct through a green extraction method. J. Food Process. Preserv. 2019, 43, e13934. [CrossRef]

64. Rafiq, S.; Kaul, R.; Sofi, S.A.; Bashir, N.; Nazir, F.; Nayik, G.A. Citrus peel as a source of functional ingredient: A review. J. Saudi Soc. Agric. Sci. 2018, 17, 351-358. [CrossRef] 
65. Fava, F.; Zanaroli, G.; Vannini, L.; Guerzoni, E.; Bordoni, A.; Viaggi, D.; Robertson, J.; Waldron, K.; Bald, C.; Esturo, A.; Talens, C. New advances in the integrated management of food processing by-products in Europe: Sustainable exploitation of fruit and cereal processing by-products with the production of new food products (NAMASTE EU). New Biotechnol. 2013, 30, 647-655. [CrossRef]

66. Figuerola, F.; Hurtado, M.L.; Estevez, A.M.; Chiffelle, I.; Asenjo, F. Fibre concentrates from apple pomace and citrus peel as potential fibre sources for food enrichment. Food Chem. 2005, 91, 395-401. [CrossRef]

67. Bravo, J.; Monente, C.; Juaniz, I.; De Pena, M.P.; Cid, C. Influence of extraction process on antioxidant capacity of spent coffee. Food Res. Int. 2013, 50, 610-616. [CrossRef]

68. Batista, J.R.; de Morais, M.P.; Caliari, M.; Soares, J. Physical, microbiological and sensory quality of gluten-free biscuits prepared from rice flour and potato pulp. J. Food Nutr. Res. 2016, 55, 101-107.

69. Neves, L.; Ribeiro, R.; Oliveira, R.; Alves, M.M. Enhancement of methane production from barley waste. Biomass Bioenergy 2006, 30, 599-603. [CrossRef]

70. Battestin, V.; Macedo, G.A. Tannase production by Paecilomyces variotii. Bioresour. Technol. 2007, 98, 1832-1837. [CrossRef] [PubMed]

71. Murthy, P.S.; Naidu, M.M. Sustainable management of coffee industry by-products and value addition-A review. Resour. Conserv. Recycl. 2012, 66, 45-58. [CrossRef]

72. Saini, A.; Panesar, P.; Bera, M. Valorization of fruits and vegetables waste through green extraction of bioactive compounds and their nanoemulsions-based delivery system. Bioresour. Bioprocess. 2019, 6, 1-12. [CrossRef]

73. Scherhaufer, S.; Moates, G.; Hartikainen, H.; Waldron, K.; Obersteiner, G. Environmental impacts of food waste in Europe. Waste Manag. 2018, 77, 98-113. [CrossRef] [PubMed]

74. Hall, K.; Guo, J.; Dore, M.; Chow, C. The Progressive Increase of Food Waste in America and Its Environmental Impact. PLoS ONE 2009, 4, e7940. [CrossRef]

75. Alvarez, M.; Cabred, S.; Ramirez, C.; Fanovich, M. Valorization of an agroindustrial soybean residue by supercritical fluid extraction of phytochemical compounds. J. Supercrit. Fluids 2019, 143, 90-96. [CrossRef]

76. Cannell, R.J. (Ed.) Natural Products Isolation; Humana Press: Totowa, NJ, USA, 1998; Volume 4, pp. 480.

77. Ameer, K.; Shahbaz, H.; Kwon, J. Green Extraction Methods for Polyphenols from Plant Matrices and Their Byproducts: A Review. Compr. Rev. Food Sci. Food Saf. 2017, 16, 295-315. [CrossRef]

78. Munir, M.; Kheirkhah, H.; Baroutian, S.; Quek, S.; Young, B. Subcritical water extraction of bioactive compounds from waste onion skin. J. Clean. Prod. 2018, 183, 487-494. [CrossRef]

79. Cravotto, G.; Binello, A.; Orio, L. Green extraction techniques for high quality natural products. Agro Food Industry Hi Tech 2011, $22,24-36$.

80. Tiwari, B. Ultrasound: A clean, green extraction technology. Trends Anal. Chem. 2015, 71, 100-109. [CrossRef]

81. Lakka, A.; Grigorakis, S.; Karageorgou, I.; Batra, G.; Kaltsa, O.; Bozinou, E.; Lalas, S.; Makris, D.P. Saffron Processing Wastes as a Bioresource of High-Value Added Compounds: Development of a Green Extraction Process for Polyphenol Recovery Using a Natural Deep Eutectic Solvent. Antioxidants 2019, 8, 586. [CrossRef] [PubMed]

82. Anastas, P.; Zimmerman, J. Peer Reviewed: Design Through the 12 Principles of Green Engineering. Environ. Sci. Technol. 2003, 37, 94A-101A. [CrossRef]

83. Chemat, F.; Abert Vian, M.; Ravi, H.K.; Khadhraoui, B.; Hilali, S.; Perino, S.; Fabiano Tixier, A.S. Review of alternative solvents for green extraction of food and natural products: Panorama, principles, applications and prospects. Molecules 2019, $24,3007$. [CrossRef]

84. Chemat, F.; Abert-Vian, M.; Fabiano-Tixier, A.; Strube, J.; Uhlenbrock, L.; Gunjevic, V.; Cravotto, G. Green extraction of natural products. Origins, current status, and future challenges. Trends Anal. Chem. 2019, 118, 248-263. [CrossRef]

85. Chemat, F.; Rombaut, N.; Sicaire, A.; Meullemiestre, A.; Fabiano-Tixier, A.; Abert-Vian, M. Ultrasound assisted extraction of food and natural products. Mechanisms, techniques, combinations, protocols and applications. A review. Ultrason. Sonochem. 2017, 34, 540-560. [CrossRef]

86. Karaj, S.; Müller, J. Optimizing mechanical oil extraction of Jatropha curcas L. seeds with respect to press capacity, oil recovery and energy efficiency. Ind. Crop. Prod. 2011, 34, 1010-1016. [CrossRef]

87. Chemat, F.; Fabiano-Tixier, A.S.; Vian, M.A.; Allaf, T.; Vorobiev, E. Solvent-free extraction of food and natural products. TrAC Trends Anal. Chem. 2015, 71, 157-168. [CrossRef]

88. Putnik, P.; Lorenzo, J.M.; Barba, F.J.; Roohinejad, S.; Režek Jambrak, A.; Granato, D.; Montesano, D.; Bursać Kovačević, D. Novel food processing and extraction technologies of high-added value compounds from plant materials. Foods 2018, 7, 106. [CrossRef]

89. Rombaut, N.; Tixier, A.; Bily, A.; Chemat, F. Green extraction processes of natural products as tools for biorefinery. Biofuels Bioprod. Biorefin. 2014, 8, 530-544. [CrossRef]

90. Panja, P. Green extraction methods of food polyphenols from vegetable materials. Curr. Opin. Food Sci. 2018, 23, 173-182. [CrossRef]

91. Brunner, G. Supercritical fluids: Technology and application to food processing. J. Food Eng. 2005, 67, 21-33. [CrossRef]

92. Sihvonen, M. Advances in supercritical carbon dioxide technologies. Trends Food Sci. Technol. 1999, 10, 217-222. [CrossRef]

93. Azmir, J.; Zaidul, I.; Rahman, M.; Sharif, K.; Mohamed, A.; Sahena, F.; Jahurul, M.; Ghafoor, K.; Norulaini, N.; Omar, A. Techniques for extraction of bioactive compounds from plant materials: A review. J. Food Eng. 2013, 117, 426-436. [CrossRef] 
94. Yin, J.; Wang, A.; Wei, W.; Liu, Y.; Shi, W. Analysis of the operation conditions for supercritical fluid extraction of seed oil. Sep. Purif. Technol. 2005, 43, 163-167. [CrossRef]

95. Herrero, M.; Cifuentes, A.; Ibanez, E. Sub- and supercritical fluid extraction of functional ingredients from different natural sources: Plants, food-by-products, algae and microalgaeA review. Food Chem. 2006, 98, 136-148. [CrossRef]

96. de Andrade Lima, M.; Kestekoglou, I.; Charalampopoulos, D.; Chatzifragkou, A. Supercritical Fluid Extraction of Carotenoids from Vegetable Waste Matrices. Molecules 2019, 24, 466. [CrossRef] [PubMed]

97. Buszewski, B.; Rafińska, K.; Cvetanovic, A.; Walczak, J.; Krakowska, A.; Rudnicka, J.; Zekovic, Z. Phytochemical analysis and biological activity of Lupinus luteus seeds extracts obtained by supercritical fluid extraction. Phytochem. Lett. 2019, 30, 338-348. [CrossRef]

98. de Lucas, A.; Martinez de la Ossa, E.; Rincon, J.; Blanco, M.; Gracia, I. Supercritical fluid extraction of tocopherol concentrates from olive tree leaves. J. Supercrit. Fluids 2002, 22, 221-228. [CrossRef]

99. Sabio, E.; Lozano, M.; Montero de Espinosa, V.; Mendes, R.; Pereira, A.; Palavra, A.; Coelho, J. Lycopene and $\beta$-Carotene Extraction from Tomato Processing Waste Using Supercritical $\mathrm{CO}_{2}$. Ind. Eng. Chem. Res. 2003, 42, 6641-6646. [CrossRef]

100. Macias-Sanchez, M.; Mantell, C.; Rodriguez, M;, Martinez de la Ossa, E.; Lubian, L; Montero, O. Supercritical fluid extraction of carotenoids and chlorophyll a from Nannochloropsis gaditana. J. Food Eng. 2005, 66, 245-251. [CrossRef]

101. Fornari, T.; Vicente, G.; Vazquez, E.; García-Risco, M.; Reglero, G. Isolation of essential oil from different plants and herbs by supercritical fluid extraction. J. Chromatogr. A 2012, 1250, 34-48. [CrossRef]

102. Capuzzo, A.; Maffei, M.; Occhipinti, A. Supercritical Fluid Extraction of Plant Flavors and Fragrances. Molecules 2013, 18, 7194-7238. [CrossRef] [PubMed]

103. Esclapez, M.; Garcia-Perez, J.; Mulet, A.; Carcel, J. Ultrasound-Assisted Extraction of Natural Products. Food Eng. Rev. 2011, 3, 108-120. [CrossRef]

104. Chemat, F.; Zill-e-Huma.; Khan, M. Applications of ultrasound in food technology: Processing, preservation and extraction. Ultrason. Sonochem. 2011, 18, 813-835. [CrossRef] [PubMed]

105. Safdar, M.N.; Kausar, T.; Jabbar, S.; Mumtaz, A.; Ahad, K.; Saddozai, A.A. Extraction and quantification of polyphenols from kinnow (Citrus reticulate L.) peel using ultrasound and maceration techniques. J. Food Drug Anal. 2017, 25, 488-500. [CrossRef] [PubMed]

106. Safdar, M.N.; Kausar, T.; Nadeem, M. Comparison of Ultrasound and Maceration Techniques for the Extraction of Polyphenols from the Mango Peel. J. Food Process. Preserv. 2016, 41, e13028. [CrossRef]

107. Hao, J.; Han, W.; Huang, S.; Xue, B.; Deng, X. Microwave-assisted extraction of artemisinin from Artemisia annua L. Sep. Purif. Technol. 2002, 28, 191-196. [CrossRef]

108. Singh, A.; Nair, G.; Liplap, P.; Gariepy, Y.; Orsat, V.; Raghavan, V. Effect of Dielectric Properties of a Solvent-Water Mixture Used in Microwave-Assisted Extraction of Antioxidants from Potato Peels. Antioxidants 2014, 3, 99-113. [CrossRef]

109. Mandal, V.; Mohan, Y.; Hemalatha, S. Microwave Assisted Extraction-An Innovative and Promising Extraction Tool for Medicinal Plant Research. Pharmacogn. Rev. 2007, 1,7-18.

110. Kratchanova, M.; Pavlova, E.; Panchev, I. The effect of microwave heating of fresh orange peels on the fruit tissue and quality of extracted pectin. Carbohydr. Polym. 2004, 56, 181-185. [CrossRef]

111. Eskilsson, S.C.; Björklund, E. Analytical-scale microwave-assisted extraction. J. Chromatogr. A 2000, 902, 227-250. [CrossRef]

112. Zhongdong, L.; Guohua, W.; Yunchang, G.; Kennedy, J. Image study of pectin extraction from orange skin assisted by microwave. Carbohydr. Polym. 2006, 64, 548-552. [CrossRef]

113. Chen, S.; Spiro, M. Study of Microwave Extraction of Essential Oil Constituents from Plant Materials. J. Microw. Power Electromagn. Energy 1994, 29, 231-241. [CrossRef]

114. Mattina, M.; Berger, W.; Denson, C. Microwave-Assisted Extraction of Taxanes from Taxus Biomass. J. Agric. Food Chem. 1997, 45, 4691-4696. [CrossRef]

115. Pan, X.; Niu, G.; Liu, H. Microwave-assisted extraction of tea polyphenols and tea caffeine from green tea leaves. Chem. Eng. Process. Process. Intensif. 2003, 42, 129-133. [CrossRef]

116. Proestos, C.; Komaitis, M. Application of microwave-assisted extraction to the fast extraction of plant phenolic compounds. LWT Food Sci. Technol. 2003, 41, 652-659. [CrossRef]

117. Saoud, A.; Yunus, R.; Aziz, R. Microwave-Assisted Extraction of Essential Oil from Eucalyptus: Study of the Effects of Operating Conditions. J. Eng. Res. 2006, 3, 31. [CrossRef]

118. Xiao, X.; Wang, J.; Wang, G.; Wang, J.; Li, G. Evaluation of vacuum microwave-assisted extraction technique for the extraction of antioxidants from plant samples. J. Chromatogr. A 2009, 1216, 8867-8873. [CrossRef]

119. Sadh, P.K.; Duhan, S.; Duhan, J.S. Agro-industrial wastes and their utilization using solid state fermentation: A review. Bioprocess 2018, 5, 1-15. [CrossRef]

120. Hee, L.Y. Waste Management and Economic Growth. World Cities Summit Issue; 2008. Available online: https://www.csc.gov.sg/ articles / waste-management-and-economic-growth (accessed on 1 October 2021).

121. Wei, J.; Liang, G.; Alex., J.; Zhang, T.; Ma, C. Research Progress of Energy Utilization of AgriculturalWaste in China: Bibliometric Analysis by Citespace. Sustainability 2020, 12, 812. [CrossRef]

122. Atinkut, H.B.; Yan, T.; Zhang, F.; Qin, S.; Gai, H.; Liu, Q. Cognition of agriculture waste and payments for a circular agriculture model in Central China. Sci. Rep. 2020, 10, 1-15. [CrossRef] 
123. Wang, B.; Dong, F.; Chen, M.; Zhu, J.; Tan, J.; Fu, X.; Wang, Y.; Chen, S. Advances in recycling and utilization of agricultural wastes in China: Based on environmental risk, crucial pathways, influencing factors, policy mechanism. Procedia Environ. Sci. 2016, 31, 12-17. [CrossRef]

124. Din, G.Y.; Cohen, Y. Modeling Municipal Solid Waste Management in Africa: Case Study of Matadi, the Democratic Republic of Congo. J. Environ. Prot. 2012, 4, 435-445. [CrossRef]

125. Gontard, N.; Sonesson, U.; Birkved, M.; Majone, M.; Bolzonella, D.; Celli, A.; Angellier-Coussy, H.; Jang, G-W.; Verniquet, A.; Broeze, J.; Schaer, B.; Batista, A.P.; Sebok, A. A research challenge vision regarding management of agricultural waste in a circular bio-based economy. Crit. Rev. Environ. Sci. Technol. 2018, 48, 614-654. [CrossRef]

126. Donner, M.; Verniquet, A.; Broeze, J.; Kayser, K.; De Vries, H. Critical success and risk factors for circular business models valorising agricultural waste and by-products. Resour. Conserv. Recycl. 2021, 165, 105236. [CrossRef] 